\title{
Hippocampal $\mathrm{Ga}_{\mathrm{q} / 11}$ but not $\mathrm{G} \alpha_{0}$-coupled receptors are altered in aging
}

\author{
Joseph A. McQuail ${ }^{1}$, Kathleen N. Davis ${ }^{2}$, Frances Miller ${ }^{3}$, Robert E. Hampson ${ }^{1,3}$, Samuel A. \\ Deadwyler $^{1,3}$, Allyn C. Howlett ${ }^{1,3}$, and Michelle M. Nicolle ${ }^{1,2,3}$ \\ ${ }^{1}$ Program in Neuroscience, Wake Forest Graduate School of Arts \& Sciences, Winston-Salem \\ NC, 27157, USA \\ ${ }^{2}$ Department of Internal Medicine - Section on Gerontology, Wake Forest School of Medicine, \\ Winston-Salem NC, 27157, USA \\ ${ }^{3}$ Department of Physiology and Pharmacology, Wake Forest School of Medicine, Winston-Salem \\ NC, 27157, USA
}

\begin{abstract}
Normal aging may limit the signaling efficacy of certain GPCRs by disturbing the function of specific $\mathrm{Ga}$-subunits and leading to deficient modulation of intracellular functions that subserve synaptic plasticity, learning and memory. Evidence suggests that $\mathrm{Ga}_{\mathrm{q} / 11}$ is more sensitive to the effects of aging relative to other $\mathrm{Ga}$-subunits, including $\mathrm{Ga}_{0}$. To test this hypothesis, the functionality of $\mathrm{Ga}_{\mathrm{q} / 11}$ and $\mathrm{Ga}_{\mathrm{o}}$ were compared in the hippocampus of young (6 months) and aged (24 months) F344 $\times \mathrm{BNF}_{1}$ hybrid rats assessed for spatial learning ability. Basal GTP $\gamma \mathrm{S}$ binding to $\mathrm{Ga}_{\mathrm{q} / 11}$ was significantly elevated in aged rats relative to young and but not reliably associated with spatial learning. $\mathrm{mAChR}$ stimulation of $\mathrm{Ga}_{\mathrm{q} / 11}$ with oxotremorine-M produced equivocal GTP $\gamma$ S-binding between age groups although values tended to be lower in the aged hippocampus and were inversely related to basal activity. Downstream $\mathrm{Ga}_{\mathrm{q} / 11}$ function was measured in hippocampal subregion CA1 by determining changes in $\left[\mathrm{Ca}^{2+}\right]_{i}$ after $\mathrm{mAChR}$ and mGluR (DHPG) stimulation. mAChR-stimulated peak change in $\left[\mathrm{Ca}^{2+}\right]_{i}$ was lower in aged CA1 relative to young while mGluR-mediated integrated $\left[\mathrm{Ca}^{2+}\right]_{i}$ responses tended to be larger in aged. GPCR modulation of $\left[\mathrm{Ca}^{2+}\right]_{i}$ was observed to depend on intracellular stores to a greater degree in aged than young. In contrast, measures of $\mathrm{Ga}_{0}$-mediated GTP $\gamma \mathrm{S}$-binding were stable across age, including basal, mAChR-, $\mathrm{GABA}_{\mathrm{B}} \mathrm{R}$ (baclofen)-stimulated levels. Overall, the data indicate that aging selectively modulates the activity of $\mathrm{Ga}_{\mathrm{q} / 11}$ within the hippocampus leading to deficient modulation of $\left[\mathrm{Ca}^{2+}\right]_{\mathrm{i}}$ following stimulation of mAChRs but these changes are not related to spatial learning.
\end{abstract}

\section{Introduction}

G-protein coupled receptors (GPCRs) interact with a variety of Ga-subunits and effectors, giving rise to considerable diversity in signal transduction and resulting in the modulation of

(C) 2013 Elsevier Ltd. All rights reserved.

Address correspondence to: Joseph A. McQuail, B.S., Neuroscience Program, Wake Forest University Graduate School of Arts \& Sciences, Medical Center Boulevard, Winston-Salem, NC 27157, jmcquail@ wakehealth.edu, Telephone: (336) 713-1515; Fax: (336) 713-1545.

Publisher's Disclaimer: This is a PDF file of an unedited manuscript that has been accepted for publication. As a service to our customers we are providing this early version of the manuscript. The manuscript will undergo copyediting, typesetting, and review of the resulting proof before it is published in its final citable form. Please note that during the production process errors may be discovered which could affect the content, and all legal disclaimers that apply to the journal pertain. 
a variety of cellular processes including cell excitability, kinase activity, intracellular $\mathrm{Ca}^{2+}$ concentration $\left(\left[\mathrm{Ca}^{2+}\right]_{i}\right)$, neurotransmitter release and gene expression. GPCRs transduce extracellular signals via an associated G-protein heterotrimer that includes a $\mathrm{Ga}$-subunit bound to a GDP molecule under resting conditions. In response to neurotransmitter binding, the transmembrane receptor protein undergoes a conformal change that drives a GTPexchange reaction at the Ga-subunit. The active GTP-bound Ga-subunit can then modulate the activity of effector proteins until the GTP is hydrolyzed back to GDP by the Gasubunit's intrinsic enzymatic activity, thus terminating signaling action. Acetylcholine, glutamate and $\gamma$-amino butyric acid (GABA), each interact with a subset of GPCRs, but the consequences for neural activity are subtype-dependent. M1 muscarinic acetylcholine receptors (mAChR) and Group I metabotropic glutamate receptors (mGluR), including mGluR1 and mGluR5, couple to $\mathrm{Ga}_{\mathrm{q}}$ and $\mathrm{Ga}_{11}$ that stimulate phospholipase C (PLC) to catalyze the formation of inositol phosphates (IP) and diacylglycerol (DAG) and subsequently releases intracellular $\mathrm{Ca}^{2+}$ stores (ICS) via inositol triphosphate receptors (IP3Rs; reviewed in Caulfield and Birdsall, 1998; Bordi and Ugolini, 1999). This signaling cascade is distinct from GPCRs, including $\mathrm{M} 2 \mathrm{mAChRs}$ and $\mathrm{GABA}_{\mathrm{B}}$ receptors $\left(\mathrm{GABA}_{\mathrm{B}} \mathrm{Rs}\right)$, that couple to $\mathrm{Ga}_{\mathrm{o}}$ and $\mathrm{Ga}_{\mathrm{i}}$ to inhibit adenylyl cyclase and limit neurotransmitter release (reviewed in Caulfield and Birdsall, 1998, Chalifoux and Carter, 2011).

Aging is associated with progressive cognitive decline as well as increased risk for neurodegenerative disorders such as Alzheimer's disease (AD). Therapeutic interventions would offer the greatest benefit if administered at the earliest indication of cognitive impairment, but the biological basis for this impairment must be sufficiently characterized to optimize therapeutic efficacy. Naturally occurring rodent models can assess the effects of normal aging on neural substrates and behavior without confounds stemming from neuropathological disease. Using these rodent models, mAChR-mediated phosphoinositide (PI) turnover has been reported as impaired (Ayyagari et al., 1998; Chouinard et al., 1995; Nicolle et al., 1999) or enhanced (Parent et al., 1995; Tandon et al., 1991) in the aged hippocampus. Similar disagreement is apparent in studies of Group I mGluR signal transduction (Nicolle et al., 1999; Parent et al., 1995). Comparatively less is known about the integrity of $\mathrm{M} 2 \mathrm{mAChR}$ - or $\mathrm{GABA}_{\mathrm{B}} \mathrm{R}$-stimulated signaling in the aged hippocampus, but compounds that block either $\mathrm{M} 2 \mathrm{mAChRs}$ or $\mathrm{GABA}_{\mathrm{B}}$ Rs enhance learning and memory in aged rats (Froestl et al., 2004; Lasarge et al., 2009; Quirion et al., 1995). However, it is unclear if these benefits are derived from reversing age-related changes to GPCRs or indirectly promoting postsynaptic activity by facilitating neurotransmitter release.

Given the complex relationship between GPCRs and associated signal transduction mechanisms, this study presents findings from a series of comparative pharmacological analyses designed to determine whether aging selectively impairs receptor-stimulated activation of $\mathrm{Ga}_{\mathrm{q} / 11}$ leading to insufficient modulation of subsequent neural responses within the hippocampus of young adult and aged rats that were characterized for spatial learning. First, this study used $\mathrm{mAChR}$ and $\mathrm{GABA}_{\mathrm{B}} \mathrm{R}$ agonist-stimulated $\left[{ }^{35}\right.$ S $]$ guanosine- $5^{\prime}$ $\mathrm{O}$-(3-thio)triphosphate (GTP $\gamma \mathrm{S}$ )-binding to assess functional coupling of these receptors to specific $\mathrm{Ga}$-subunits that were biochemically verified using an immunocapture scintillation proximity assay (SPA). Subsequently, activity downstream of mAChRs or Group I mGluRs was examined by measuring agonist-stimulated changes to $\left[\mathrm{Ca}^{2+}\right]_{i}$.

\section{Materials and Methods}

\section{1. Subjects}

Male, Fischer $344 \times$ Brown Norway $F_{1}$ hybrid rats were obtained from the National Institutes of Aging rodent colony maintained by Harlan-Sprague-Dawley, Inc., 
(Indianapolis, IN, USA) and were 6 months of age (young; $\mathrm{n}=21$ ) or 24 months of age (aged; $n=47$ ) at the time of behavioral training. All animals were housed in a facility approved by the International Association for the Assessment and Accreditation of Laboratory Animal Care at Wake Forest University School of Medicine. The Institutional Animal Care and Use Committee of Wake Forest University approved all protocols described in these studies.

\subsection{Behavioral Testing in Morris Water Maze}

Rats were behaviorally characterized using a standardized place-learning task developed to optimize detection of age-associated changes in spatial learning (Gallagher et al., 1993). Rats trained 3 trials a day for 8 days to navigate to a submerged platform using spatial cues surrounding the maze. Rats were placed into the water at one of four equally spaced start positions in a counterbalanced order and allowed $90 \mathrm{~s}$ to locate the platform after which time they were guided to the platform. Rats remained on the platform for $30 \mathrm{~s}$ before transfer to a holding cage for $30 \mathrm{~s}$. Every sixth trial (i.e. the third trial on days 2, 4, 6 and 8) was a probe where the platform was lowered and inaccessible during the first $30 \mathrm{~s}$ of the trial then subsequently raised for escape. Following place-training, rats received a single session of 6 cued trials, escaping to a visible black platform extending $2 \mathrm{~cm}$ above the water surface, to assess sensorimotor function and motivation. Data were acquired via a video camera mounted above the maze connected to a digital video recorder and computer running Ethovision software (Noldus, Leesburg, VA, USA). Cumulative distance and average distance from platform assessed training and probe trial performance, respectively. Values from the second, third and fourth probe trials were summed to produce a "proximity score", a graded measure summarizing individual performance (Gallagher et al., 1993; Bizon et al., 2009; Nieves-Martinez et al., 2012).

\subsection{Hippocampal Microdissection and Membrane Preparation}

Approximately 2 weeks after the completion of behavioral testing, rats were decapitated, the brain removed, and hippocampi dissected on an ice-cold plate. $1 \mathrm{~mm}$-thick transverse sections were made through the septal-temporal axis using a tissue chopper and subdissected into dentate gyrus (DG; including the hilus), CA3 (including CA2) and CA1 regions. Regions from both hippocampi were pooled, frozen on dry ice and stored at $-80^{\circ} \mathrm{C}$ until used for membrane preparation as described in (McQuail et al., 2012). Membrane protein content was measured using the Pierce bicinchoninic acid assay kit (Rockford, IL, USA) and aliquots were stored at $-80^{\circ} \mathrm{C}$ until used for GTP $\gamma$ S-binding assays.

\subsection{GTPyS-Binding and Anti-G-protein Scintillation Proximity Assay}

All reagents were purchased from Sigma-Aldrich (Saint Louis, MO, USA), unless otherwise stated. GTP $\gamma$ S-binding reactions were conducted in triplicate in 96-well Opti-plates (PerkinElmer, Waltham, MA, USA). The reaction buffer contained $100 \mathrm{mM} \mathrm{NaCl}, 5 \mathrm{mM}$ $\mathrm{MgCl}_{2}$ in $50 \mathrm{mM}$ HEPES (pH 7.4). To unmask $\mathrm{Ga}_{\mathrm{q} / 11}$ activity, membranes were pre-treated with $10 \mathrm{mM} N$-ethylmaleimide for 30 minutes on ice (Salah-Uddin et al., 2008) and guanosine $5^{\prime}$-diphosphate concentration was $0.1 \mathrm{mM}$ (Delapp et al., 1999; Porter et al., 2002). For the $\mathrm{Ga}_{\mathrm{o}}$ assay, GDP concentration was $50 \mathrm{mM}$ (Delapp et al., 1999). Nonspecific binding was determined in the presence of $10 \mu \mathrm{M}$ GTP $\gamma$ S. Basal GTP $\gamma$ S-binding was measured in the absence of any experimental compounds. $100 \mu \mathrm{M}$ oxotremorine-M or $300 \mu \mathrm{M}$ baclofen (Tocris, Ellison, MO, USA) stimulated $\mathrm{mAChR}$ and $\mathrm{GABA}_{\mathrm{B}} \mathrm{Rs}$, respectively. These concentrations were selected to produce maximal GTP $\gamma \mathrm{S}$-binding based upon prior studies examining total or Ga-subunit specific GTP-exchange in rodent brain (Delapp et al., 1999; McQuail et al., 2012; Porter et al., 2002; Zhang et al., 2007). Ten micrograms of membrane protein was added to each well and equilibrated at room temperature for 30 minutes. GTP $\gamma$ S-binding was initiated by the addition of $500 \mathrm{pM}$ 
$\left[{ }^{35}\right.$ S]GTP $\gamma \mathrm{S}$ (PerkinElmer) to a final volume of $200 \mu \mathrm{l} /$ reaction. After 60 minutes, IGEPAL CA-630 was added to a final concentration of $0.3 \%(\mathrm{v} / \mathrm{v})$ with agitation at $+4^{\circ} \mathrm{C}$ for 30

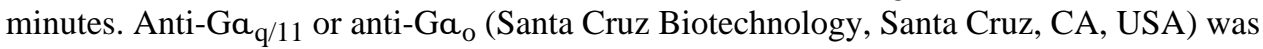
added at a final dilution of 1:100 and incubated for 1 hour at $+4^{\circ} \mathrm{C}$. Anti-IgG-coated scintillation proximity assay beads (PerkinElmer) were suspended in $25 \mathrm{ml}$ of $50 \mathrm{mM}$ HEPES and $50 \mu \mathrm{l}$ added per well then incubated for 30 minutes at $+4^{\circ} \mathrm{C}$. Plates were centrifuged and counted in a TopCount scintillating microplate reader (PerkinElmer). Basal GTP $\gamma$ S-binding (counts per minute; CPM) was determined by subtracting non-specific activity. Agonist-stimulated values were transformed to "percent over basal" [\% = (stimulated-basal)/(basal)*100] to facilitate comparisons between age groups and subregions or "net CPM" values (i.e. basal subtracted from stimulated) for correlation with basal activity.

\subsection{Hippocampal Slice Preparation and Calcium Imaging}

Transverse hippocampal slices $(250 \mu \mathrm{m})$ were prepared and loaded with Calcium GreenAM (Molecular Probes, Eugene, OR, USA) as described in (Hampson et al., 2011). In contrast to intracellular injection, acetoxymethyl (AM) ester derivatives of fluorescent indicators allow for the labeling of multiple cells per slice/field of view. Imaging was performed on CA1 cells with an upright confocal microscope (Nikon, New York, NY, USA) equipped with a water-immersion objective, a Hamamatsu Orca-ER digital camera and an Ultraview spinning disc confocal system (PerkinElmer). Calcium Green emission images $(500-600 \mathrm{~nm})$ were acquired by laser excitation at $488 \mathrm{~nm}$ and sampled at $0.3 \mathrm{~s}$ intervals. A piezoelectric "stepping" motor advanced the objective through the focal plane to acquire 40 vertical slices $(2.5 \mu \mathrm{m})$ per field, producing a complete three-dimensional image every $12 \mathrm{~s}$. Slices were perfused with artificial cerebrospinal fluid (ACSF; $126 \mathrm{mM} \mathrm{NaCl}, 20 \mathrm{mM}$ $\mathrm{NaHCO}_{3}, 5 \mathrm{mM} \mathrm{KCl}, 2 \mathrm{mM} \mathrm{MgCl} 2,2.5 \mathrm{mM} \mathrm{CaCl}_{2}, 10 \mathrm{mM}$ glucose in $20 \mathrm{mM}$ HEPES [pH 7.4]) for $2 \mathrm{~min}$ to determine baseline fluorescence and then perfused with either $50 \mu \mathrm{M}$ oxotremorine-M or $50 \mu \mathrm{M}(S)$-3,5-dihydroxyphenylglycine (DHPG; Group I mGluR agonist; Tocris Bioscience) in ACSF for 3 minutes. Drug perfusion was followed by 5 minute ACSF washout. Each slice was then incubated with $50 \mu \mathrm{M}$ cyclopiazonic acid (CPA; Tocris Bioscience) for 10 minutes to deplete intracellular calcium stores (Soler et al., 1998) and the drug stimulation protocol was repeated. Calcium imaging results were expressed as percentage change in cell soma fluorescence $(\Delta \mathrm{F})$ of baseline Calcium Green fluorescence $\left(\mathrm{F}_{0}\right.$; average of first $120 \mathrm{~s}$ of recording). This relatively quantitative approach is necessary because uptake of the indicator dye is dependent upon infiltration of the cell plasma membrane followed by cleavage of the dye from the conjugated acetoxymethyl group by endogenous esterases to facilitate cytosolic localization and retention within the cell. Peak change in fluorescence $\left(\Delta \mathrm{F} / \mathrm{F}_{0}\right.$; i.e. the single greatest value observed during agonist administration) was obtained from each cell under all conditions to determine maximal response and the cumulative effect of agonist-stimulated change to $\left[\mathrm{Ca}^{2+}\right]_{\mathrm{i}}$ was evaluated by calculating area under the curve (AUC) using the integral of the response calculated in GraphPad Prism 5 software (LaJolla, CA, USA).

\subsection{Statistical analyses}

Data are presented as the mean \pm standard error. Independent- or paired-samples $t$-tests and repeated measures analysis of variance (RMANOVA) were performed using GraphPad Prism 5 software. RMANOVAs were followed with Bonferroni post hoc tests to evaluate significant differences while correcting for multiple comparisons. In all statistical comparisons, $p<0.05$ was considered significant. GTP $\gamma \mathrm{S}$-binding and $\left[\mathrm{Ca}^{2+}\right]_{\mathrm{i}}$ results that were significantly different between young and aged rats were tested for correlation with proximity scores; bivariate correlations were performed for young and aged in a single analysis as well as separately for each age group. 


\section{Results}

\subsection{Spatial learning}

While young and aged rats did not differ on the first training trial (see supplemental materials and Fig S1), there were main effects of age $\left(F_{(1,66)}=31.34, p<0.001\right)$ and training trial block $\left(F_{(3,198)}=82.93, p<0.001\right)$ as well as an interaction between these two variables $\left(F_{(3,90)}=9.62, p<0.001\right)$. Post hoc comparisons revealed aged rats swam a greater cumulative distance from the platform on the first two training blocks ( $p<0.001$ for both; Fig. 1A). Probe trial performance also differed between age groups $\left(F_{(1,66)}=65.81, p<0.001\right)$ and across trials $\left(F_{(3,198)}=9.39, p<0.001\right)$ but these factors did not interact $\left(F_{(3,198)}=0.74, p>0.5\right.$ N.S.) demonstrating poorer spatial bias for the platform location on all probes in the aged group compared to young (Post hoc: $p<0.01$ on $1^{\text {st }}$ probe and $p<0.001$ on $2^{\text {nd }}-4^{\text {th }}$ probes, Fig 1B; also see supplemental materials and Fig. S2 and S3). However, age groups performed comparably on cued, visible-platform trials $\left(t_{(66)}=1.36, p>0.1 \mathrm{~N}\right.$.S. $)$, demonstrating that spatial impairment was not related to non-cognitive factors such as swimming ability or motivation to escape to the platform (Fig. 1C; also see supplemental materials and Fig. S4). Proximity scores were significantly higher in the aged group $\left(t_{(66)}=7.65, p<0.001\right)$, consistent with searching further from the platform location, compared to young (Fig. 1D). Similar results were obtained comparing proximity scores between young and aged rats used for GTP $\gamma$ S-binding experiments $\left(t_{(30)}=4.62, p<0.001\right.$; Fig. $\left.1 \mathrm{E}\right)$, oxotremorine-M $\left[\mathrm{Ca}^{2+}\right]_{\mathrm{i}}$ imaging $\left(t_{(19)}=4.46, p<0.001\right.$; Fig. $\left.1 \mathrm{~F}\right)$ and DHPG $\left[\mathrm{Ca}^{2+}\right]_{\mathrm{i}}$ imaging $\left(t_{(13)}=4.77, p<0.001\right.$; Fig. 1G).

\subsection{Muscarinic acetylcholine receptor-stimulated GTPyS-binding to $\mathbf{G a}_{\mathbf{q} / \mathbf{1 1}}$}

Non-specific binding was not different between age groups $\left(F_{(1,30)}=0.09, p>0.7\right.$ N.S. $)$ or hippocampal subregions $\left(F_{(2,60)}=1.63, p>0.2\right.$ N.S.; data not shown). Basal GTP $\gamma$ S-binding to $\mathrm{Ga}_{\mathrm{q} / 11}$ was greater in aged rats relative to young rats; age $\times$ subregion RMANOVA revealed a main effect of age $\left(F_{(1,30)}=4.79, p<0.05\right)$, but no main effect of subregion $\left(F_{(2,60)}=0.95, p>0.3\right.$ N.S. $)$ or interaction $\left(F_{(2,60)}=0.45, p>0.6\right.$ N.S. $)$. However, when compared within each subregion, basal GTP $\gamma \mathrm{S}$-binding to $\mathrm{Ga}_{\mathrm{q} / 11}$ did not significantly differ between young and aged in DG, CA3 or CA1 (Fig. 2A). When averaged across all three subregions (Fig. 2B), a trend towards a positive correlation with proximity scores was observed for young and aged rats $(r=0.31, p<0.1)$, but no significant relationship was observed when aged rats were considered alone $(r=0.12, p>0.6$ N.S.; Fig $2 \mathrm{C}$; but see supplemental materials, Table S1 and Fig. S5 for a specific case). GTP $\gamma \mathrm{S}$-binding to $\mathrm{Ga}_{\mathrm{q} / 11}$ stimulated by oxotremorine-M did not differ as a function of age $\left(F_{(1,30)}=1.81, p>0.1\right.$ N.S.) or subregion $\left(F_{(2,60)}=2.34, p>0.1\right.$ N.S. $)$ nor did these factors interact $\left(F_{(2,60)}=0.08, p>0.9\right.$ N.S.; Fig. 2D). Although no effect of age was observed for oxotremorine-M-stimulated $\left[{ }^{35} \mathrm{~S}\right]$ GTP $\gamma \mathrm{S}$-binding to $\mathrm{Ga}_{\mathrm{q} / 11}$, given previous findings in aged rats trained in an identical manner (Chouinard et al., 1995; Zhang et al., 2007), we averaged data from all 3 subregions (Fig. 2E) for correlation with proximity scores, but observed no reliable association across all rats $(r=-0.25, p>0.3$ N.S) or in aged rats alone ( $r=-0.20, p>0.1$ N.S.; Fig. $2 F)$.

To determine whether greater basal GTP $\gamma \mathrm{S}$-binding to $\mathrm{Ga}_{\mathrm{q} / 11}$ is associated with lower mAChR-stimulated GTP $\gamma \mathrm{S}$-binding to $\mathrm{Ga}_{\mathrm{q} / 11}$, correlations were performed between basal and oxotremorine-M stimulated values (net CPMs). Basal and oxotremorine-M-stimulated GTP $\gamma$ S-binding to $\mathrm{Ga}_{\mathrm{q} / 11}$ were inversely related in the entire cohort when data from all 3 subregions were averaged ( $r=-0.40, p<0.05$; Fig $3 \mathrm{~A}$ ), although when analyzed by age, young showed a significant correlation $(r=-0.69, p<0.05)$ whereas aged rats exhibited a trend ( $r=-0.37, p<0.1$ N.S.). Within the DG, there was negative correlation between basal and stimulated GTP $\gamma$ S-binding across the entire cohort ( $r=-0.17, p>0.3$ N.S.; Fig 3B), but when comparing between age groups, young rats exhibited a negative correlation $(r=-0.67$, 
$p<0.05)$ whereas aged did not $(r=0.09, p>0.6$ N.S.). There was no significant correlation in the CA3 in the entire cohort $(r=-0.01, p>0.9$; Fig $3 \mathrm{C})$ or in either age group $\left(r_{(y o u n g}\right)=$ $-7.0 \mathrm{e}-4, p>0.9$ N.S., $r_{(\text {aged })}=-0.01, p>0.9$ N.S.). In the CA1, basal and oxotremorine-Mstimulated GTP $\gamma \mathrm{S}$-binding to $\mathrm{Ga}_{\mathrm{q} / 11}$ were inversely correlated in the total cohort $(r=-0.56$, $p<0.001$; Fig 3D) but when age groups were analyzed separately, this relationship was only significant for aged rats $(r=-0.63, p<0.01)$ and not young $(r=-0.49, p>0.1$ N.S.).

\subsection{Muscarinic acetylcholine and $\mathrm{GABA}_{B}$ receptor-stimulated GTPyS-binding to $\mathrm{Ga}_{\mathrm{o}}$}

Non-specific binding did not differ between age groups $\left(F_{(1,30)}=1.65, p>0.2\right.$, N.S. $)$ or among subregions $\left(F_{(2,60)}=1.00, p>0.3\right.$, N.S. $)$ nor did these factors interact $\left(F_{(2,60)}=1.23\right.$, $p>0.2$, N.S.; data not shown). There was a significant main effect of subregion on basal GTP $\gamma$ S-binding to $\mathrm{Ga}_{\mathrm{o}}\left(F_{(2,60)}=38.28, \mathrm{p}<0.001\right)$, but no main effect of age $\left(F_{(1,30)}=0.01\right.$, $p>0.9$, N.S. $)$ or interaction $\left(F_{(2,60)}=0.60, p>0.5\right.$ N.S.; Fig. $\left.4 \mathrm{~A}\right)$. Subsequent $t$-test comparisons demonstrated basal GTP $\gamma \mathrm{S}$-binding to $\mathrm{Ga}_{\mathrm{o}}$ was significantly different between all subregions; it was lowest in CA3 and greatest in DG with intermediate values in the CA1 ( $p<0.05$ for all comparisons). GTP $\gamma \mathrm{S}$-binding to $\mathrm{Ga}_{\mathrm{o}}$ stimulated by oxotremorine-M was significantly different among subregions $\left(F_{(2,60)}=82.46, p<0.001\right)$, but not different between age groups $\left(F_{(1,30)}=0.04, p>0.8\right.$, N.S. $)$ and there was no interaction between these two factors $\left(F_{(2,60)}=1.18, p>0.3\right.$ N.S.; Fig 4B). In contrast to basal activity, oxotremorine-Mstimulated GTP $\gamma \mathrm{S}$-binding to $\mathrm{Ga}_{\mathrm{o}}$ was lowest in the DG and greater in the CA1 with intermediate values in the CA3 ( $p<0.05$ for all comparisons). Baclofen-stimulated GTP $\gamma \mathrm{S}$ binding to $\mathrm{Ga}_{\mathrm{o}}$ was also significantly different between subregions $\left(F_{(2,60)}=8.54, p<0.001\right)$ but values were not different between age groups $\left(F_{(1,30)}=1.38, p>0.2\right.$ N.S. $)$ and there was no interaction between age and subregion $\left(F_{(2,60)}=1.36, p>0.2\right.$ N.S.; Fig. $\left.4 C\right)$. Subsequent $t$ tests indicated that baclofen-stimulated GTP $\gamma S$-binding to $\mathrm{Ga}_{\mathrm{o}}$ was lower in CA1 relative to CA3 $(p<0.001)$ and DG $(p<0.001)$ while binding was equivalent in CA3 and DG $(p>0.5$, N.S.).

\subsection{Muscarinic receptor-stimulation of intracellular calcium in CA1}

Representative $\mathrm{Ca}^{2+}$ imaging results are shown from slices prepared from young (Fig. 5A) and aged rats (Fig. 5B). When peak values from all cells were compared between age groups, oxotremorine-M-stimulated $\left[\mathrm{Ca}^{2+}\right]_{\mathrm{i}}$ was lower in aged cells relative to young $\left(t_{(206)}=2.19, p<0.05\right.$; Fig. 4B), but the AUC was not different between ages $\left(t_{(206)}=0.82\right.$, $p>0.4$ N.S.; Fig. 5F). When oxotremorine-M stimulation was repeated following CPA treatment, peak values were significantly lower in aged $\left(t_{(135)}=3.41, p<0.001\right)$, but not young $\left(t_{(71)}=1.26, p>0.2\right.$ N.S.; Fig. 4 C\&D; Fig. $\left.5 \mathrm{C}\right)$ cells. Similarly, CPA significantly attenuated AUC in aged $\left(t_{(135)}=4.09, p<0.001\right)$, but not young $\left(t_{(71)}=1.20, p>0.2\right.$ N.S.; Fig. $5 F)$. When averaged by rat, a trend towards lower peak $\left[\mathrm{Ca}^{2+}\right]_{\mathrm{i}}$ was observed in the aged group $\left(t_{(19)}=1.77, \mathrm{p}<0.1\right.$ N.S.; Fig 5D) and while decreased peak was associated with greater proximity scores in the entire sample $(r=-0.21, p<0.05)$, this relationship was not significant when aged rats were tested alone $(r=-0.38, p>0.1$; Fig 5E) There was no difference between young and aged rats when comparing $\operatorname{AUC}\left(t_{(19)}=0.81\right.$, p $>0.4$ N.S.; Fig $\left.5 F\right)$.

\subsection{Group I metabotropic glutamate receptor-stimulation of intracellular calcium in CA1}

Representative $\mathrm{Ca}^{2+}$ imaging results are shown from slices prepared from young (Fig. 6A) and aged rats (Fig. 6B). When peak values were compared between ages, DHPG-stimulated $\left[\mathrm{Ca}^{2+}\right]_{\mathrm{i}}$ was not different between young and aged cells $\left(t_{(100)}=0.75, p>0.4\right.$, NS; Fig. $\left.6 \mathrm{C}\right)$, although aged cells showed a trend towards greater AUC relative to young $\left(t_{(100)}=1.90\right.$, $p<0.1 ;$ Fig. 6E). CPA treatment depressed peak DHPG-stimulated values in young $\left(t_{(34)}=2.34, p<0.05\right.$; Fig. 5C\&D) and aged cells $\left(t_{(66)}=5.14, p<0.001\right.$; Fig. $\left.6 \mathrm{C}\right)$ but only decreased AUC in aged $\left(t_{(66)}=4.01, p<0.001\right)$ and not in young cells $\left(t_{(34)}=0.07, p>0.9\right.$; Fig. 
$6 \mathrm{E})$. When averaged by rat, there was no difference between age groups with respect to peak $\left(t_{(13)}=0.07, p>0.9\right.$; Fig. $\left.6 \mathrm{D}\right)$ or AUC $\left(t_{(13)}=1.18, p>0.2\right.$; Fig. $\left.6 \mathrm{~F}\right)\left[\mathrm{Ca}^{2+}\right]_{\mathrm{i}}$ response.

\section{Discussion}

The current data demonstrate that aging selectively alters $\mathrm{Ga}_{\mathrm{q} / 11}$-mediated GTP $\gamma \mathrm{S}$-binding as well as $\left[\mathrm{Ca}^{2+}\right]_{\mathrm{i}}$ after $\mathrm{mAChR}$ and mGluR stimulation in the hippocampus. In contrast, GTP $\gamma$ S-exchange by $\mathrm{Ga}_{\mathrm{o}}$ stimulated with oxotremorine-M or baclofen was unchanged by age. While stimulation of GTP $\gamma \mathrm{S}$-exchange by $\mathrm{Ga}_{\mathrm{q} / 11}$ via $\mathrm{mAChRs}$ was lower, though not significantly so, in all subregions of aged hippocampus, peak $\left[\mathrm{Ca}^{2+}\right]_{i}$ stimulated by this same receptor was significantly depressed in the aged CA1. Interestingly, peak Group I mGluR-stimulation of $\left[\mathrm{Ca}^{2+}\right]_{i}$ was comparable between young and aged CA1 cells but there was a trend towards greater integrated $\left[\mathrm{Ca}^{2+}\right]_{\mathrm{i}}$ response in aged cells. Whether stimulated with oxotremorine-M or DHPG, aged cells also demonstrated a greater dependence on intracellular calcium stores compared to young. Collectively, the data suggest that modest changes to $\mathrm{Ga}_{\mathrm{q} / 11}$ may impair downstream signal amplification, but additional intracellular signaling pathways may compensate in a system-specific manner.

Data indicate that aging selectively alters hippocampal receptor-mediated PI turnover due to modified receptor:G-protein coupling, but not protein expression (Aubert et al., 1995; Chouinard et al., 1995; Nicolle et al., 1999; Smith et al., 1995; Zhang et al., 2007). But evidence obtained via the PI hydrolysis assay has yielded equivocal results. Chouinard and colleagues reported that $\mathrm{mAChR}$ production of IP elicited by oxotremorine-M was decreased in the hippocampus of aged Long-Evans rats and this decrease was associated with spatial learning impairment (Chouinard et al., 1995). However, Parent and colleagues, also examining PI hydrolysis in Long-Evans rats, reported elevated IP production in aged, spatial learning-impaired rats when stimulated with the cholinergic agonist carbachol $\mathrm{CCh}$ Parent et al., 1995). Slight differences in the pharmacology of oxotremorine-M versus CCh may account for these discrepancies as additional studies examining oxotremorine-M or CCh-stimulation of CDP-DAG report either a decrease (Nicolle et al., 2001) or no effect of age (Parent et al., 1995) in the hippocampus of aged Long Evans rats, respectively. Additionally, there is also no consensus on the effect of age on basal PI turnover in the hippocampus (Ayyagari et al., 1998; Nicolle et al., 1999; Parent et al., 1995; Tandon et al., 1991).

While PI turnover assays probe only those GPCRs that signal via $\mathrm{Ga}_{\mathrm{q} / 11}$, insight from traditional GTP $\gamma$ S-binding assays is limited as many agonists exhibit poor subtype selectivity and, without modifications to detect binding to $\mathrm{Ga}_{\mathrm{q} / 11}$, results reflect a disproportionate contribution from $\mathrm{Ga}_{\mathrm{i}} / \mathrm{Ga}_{\mathrm{o}}$ (reviewed in (Milligan, 2003). However, the current data obtained via a Ga-specific SPA, may bridge the disparate PI hydrolysis findings as elevated basal activity of $\mathrm{Ga}_{\mathrm{q} / 11}$ lends credence to those studies reporting elevated basal PI hydrolysis, while modestly depressed $\mathrm{mAChR:Ga} \mathrm{q}_{\mathrm{q} / 11}$ coupling (presumably M1, e.g. Porter et al., 2002) may translate to significantly lower PI turnover downstream through deficits in signal amplification, especially given evidence for an ageassociated decrease in PLC $\beta 1$ protein levels (Nicolle et al., 1999). This assumption is strengthened by the reliable, negative association between basal and mAChR-stimulated GTP-binding in the CA1 hippocampal subregion and when values were averaged across subregions. Resolving the status of M1 activity in normal aging is imperative because mAChR-stimulated PI hydrolysis is decreased in post-mortem AD cortical samples (Greenwood et al., 1995; Jope et al., 1997), but stimulation of M1 inhibits amyloid- $\beta$ formation (Caccamo et al., 2006; Jones et al., 2008). Thus, deteriorating M1 function expedites $\mathrm{AD}$ pathology and this receptor may be a key disease-modifying target if appropriate therapies can be administered at the earliest sign of cognitive changes. 
In contrast to $\mathrm{Ga}_{\mathrm{q} / 11}, \mathrm{Ga}_{\mathrm{o}}$ activity remained stable with age. Detailed subregion analyses, however, showed agonist-dependent differences in the relative activities between DG, CA3 and $C A 1$, potentially reflecting differences in $\mathrm{M} 2$ receptor densities and $\mathrm{GABA}_{\mathrm{B}} \mathrm{R} 1$ expression profiles (Aubert et al., 1995; Fritschy et al., 1999; Quirion et al., 1995; Smith et al., 1995). Although M2 autoreceptor density is reported as stable or modestly elevated with age (Aubert et al., 1995; Quirion et al., 1995; Smith et al., 1995), cholinergic fiber length is decreased in the aged hippocampus (Ypsilanti et al., 2008). Similarly, expression of $\mathrm{GABA}_{\mathrm{B}} \mathrm{R} 2$, the subunit that mediates $\mathrm{GABA}_{\mathrm{B}} \mathrm{R}$ :G-protein coupling (Robbins et al., 2001), is unchanged in the aged hippocampus (McQuail et al., 2012) but there are fewer glutamic acid decarboxylase-67-expressing (GAD-67+) interneurons (Stanley and Shetty, 2004) and possibly greater numbers of basal forebrain GAD-67+ projection neurons innervating the hippocampus in cognitively impaired aged rats (Bañuelos et al., 2013). Thus, prior findings indicate that circuit-level changes may alter cholinergic and GABAergic modulation of the aged hippocampus while the current data indicate the activity of $\mathrm{M} 2 \mathrm{mAChRs}$ and $\mathrm{GABA}_{\mathrm{B}} \mathrm{Rs}$ is preserved with age.

Given the tendency towards decreased mAChR-stimulation of $\mathrm{Ga}_{\mathrm{q} / 11}$ in the current study and prior evidence of decreased post-synaptic $\mathrm{mAChR}$ function in aged rats (Chouinard et al., 1995; Nicolle et al., 2001; Zhang et al., 2007), it was hypothesized that oxotremorine-M would be less effective at stimulating downstream ICS release. Accordingly, there was a significant age-dependent decrease in peak oxotremorine-M-stimulated $\left[\mathrm{Ca}^{2+}\right]_{\mathrm{i}}$ of CA1 cells. As Group I mGluRs also release $\mathrm{Ca}^{2+}$ from ICS, it was surprising to find that peak DHPGstimulated $\left[\mathrm{Ca}^{2+}\right]_{\mathrm{i}}$ was not blunted in aged CA1 cells. CPA did not completely block mAChR or mGluR-stimulated $\left[\mathrm{Ca}^{2+}\right]_{\mathrm{i}}$, consistent with a role for cell membrane $\mathrm{Ca}^{2+}$ channels including N-Methyl-D-aspartate receptors (NMDARs) and voltage-gated $\mathrm{Ca}^{2+}$ channels (VGCCs). Aging is associated with decreased expression of NMDARs (Shi et al., 2007; Wenk and Barnes, 2000 but see Nicolle et al., 1996), diminished NMDAR function (Barnes et al., 1997; Potier et al., 2000; Bodhinathan et al., 2010) and increased VGCC currents and channel density (Campbell et al., 1996; Thibault and Landfield, 1996) in CA1 that may alter the balance of $\mathrm{Ca}^{2+}$ homeostasis and signaling within aged neurons. When considered together, the data indicate a selective deficit in $\mathrm{mAChR}$ modulation of $\left[\mathrm{Ca}^{2+}\right]_{\mathrm{i}}$, although a diversity of $\mathrm{Ca}^{2+}$ entry, sequestration and release processes are at work and changing with age in the CA1 area.

Post-synaptic elevation of $\left[\mathrm{Ca}^{2+}\right]_{\mathrm{i}}$ is necessary to induce synaptic plasticity, including longterm potentiation (LTP) and long-term depression (LTD). Electrophysiological and pharmacological studies have shown that aging modulates the magnitude and mechanisms of synaptic plasticity triggered by M1 mAChR or Group I mGluR-stimulation. Relative to young rats and aged rats with impaired spatial learning, aged Long-Evans rats with preserved spatial learning exhibit increased expression of a form of synaptically evoked, non-NMDAR LTD dependent on the activation of PLC via Ga $\mathrm{q}_{\mathrm{q} / 11^{-}}$coupled GPCRs (Lee et al., 2005). This phenotype was highly specific as NMDA-dependent LTD was depressed in aged animals with no relation to spatial learning and CCh-LTD was not enhanced in agedunimpaired rats, rather it was lower in aged-impaired rats. In this same study population, NMDA-dependent LTP induced by theta-burst stimulation is depressed in all aged rats, regardless of cognitive status, but unimpaired aged rats exhibit greater VGCC-dependent LTP relative to either young or age-matched rats with impaired spatial learning (Boric et al., 2008). Collectively, these data argue a switch from NMDA-dependent to NMDAindependent mechanisms of plasticity is neuroprotective and beneficial to cognitive aging. This is consistent with biochemical evidence demonstrating that excessive $\mathrm{Ca}^{2+}$ influx via NMDARs is neurotoxic (Attucci et al., 2002), and memantine, a NMDAR antagonist prescribed to AD patients (Reisberg et al., 2003), protects cultured hippocampal neurons against excitotoxic insult (Volbracht et al., 2006). However, evidence for an adaptive switch 
in plasticity is not universal. In contrast to those findings obtained in aged Long-Evans rats, increased susceptibility to NMDAR-LTD in the CA1 of aged F344 rats is associated with worse spatial retention in the water maze (Foster and Kumar, 2007), possibly due to an enhanced contribution from ICS (Kumar and Foster, 2005). In this same study population CCh-LTD and DHPG-LTD are enhanced owing to an age-dependent shift towards greater contributions from NMDARs and VGCCs (Kumar and Foster, 2007; Kumar, 2010). These latter studies implicate the age-associated shift in the induction thresholds for LTP versus LTD are largely dependent on alterations to $\left[\mathrm{Ca}^{2+}\right]_{\mathrm{i}}$ and, when activated, will recruit somewhat different mechanisms between young and aged rats. Thus it remains to be resolved whether or not GPCRs provide an alternate mechanism to support synaptic plasticity in aging and under what circumstances GPCRs will facilitate LTP rather than LTD in the aged CA1 area.

When attempting to reconcile divergent conclusions such as beneficial versus maladaptive changes to GPCR modulation of plasticity, an increased $\mathrm{Ca}^{2+} / \mathrm{Mg}^{2+}$ ratio in recording solutions used in some studies (e.g. Lee et al., 2005) relative to others (e.g. Foster and Kumar, 2007) will facilitate the induction of LTD over LTP (reviewed in Burke and Barnes, 2010 ), thus underscoring an important need to evaluate receptor-mediated changes to $\left[\mathrm{Ca}^{2+}\right]_{\mathrm{i}}$ to better inform studies of synaptic plasticity. Emphasizing specific evaluation of $\left[\mathrm{Ca}^{2+}\right]_{\mathrm{i}}$ following application of selective GPCR agonists, the data show aged cells significantly depend on ICS to elevate $\left[\mathrm{Ca}^{2+}\right]_{\mathrm{i}}$ following mAChR-stimulation whereas young cells do not, consistent with an age-dependent shift towards ICS that facilitates LTD. Furthermore, peak mAChR-stimulated $\left[\mathrm{Ca}^{2+}\right]_{\mathrm{i}}$ was lower in aged CA1, possibly consistent with the modest rise in $\mathrm{Ca}^{2+}$ needed to induce LTD relative to LTP, explaining enhanced LTD following $\mathrm{mAChR}$ activation. However, the relationship between this parameter and learning is unclear because peak $\left[\mathrm{Ca}^{2+}\right]_{i}$ was not different between ages when conducting a subject-based analysis, although a trend towards lower $\left[\mathrm{Ca}^{2+}\right]_{i}$ was observed. Peak Group I mGluR-stimulated $\left[\mathrm{Ca}^{2+}\right]_{\mathrm{i}}$ was not different between young and aged groups. However, aged cells tended to demonstrate a greater, CPA-sensitive integrated $\left[\mathrm{Ca}^{2+}\right]_{\mathrm{i}}$ response relative to young leading to speculation that this exaggerated response is a factor in age-dependent changes to mGluRmediated plasticity. DHPG application elicits both rapid ICS release via mGluR1 and delayed potentiation of NMDARs via mGluR5 (Mannaioni et al., 2001). Therefore, preserved peak followed by sustained elevation of $\left[\mathrm{Ca}^{2+}\right]_{\mathrm{i}}$ in aged cells is consistent with increased contributions from mGluR1 and NMDARs (via mGluR5), respectively, that enhance DHPG-LTD in the aged CA1 (Kumar and Foster, 2007). However, such a mechanistic shift is likely maladaptive. NMDAR-stimulated release of ICS via ryanodine receptors (RyRs) is implicated in the progression of pathology in transgenic AD mice (Goussakov et al., 2010; Oulès et al., 2012) and levetiracetam, an anticonvulsant that blocks IP3R and RyR-mediated ICS release (Nagarkatti et al., 2008), reverses cognitive impairments in aged rats (Koh et al., 2010) and older humans with mild cognitive impairment (Bakker et al., 2012).

Robust stimulation will trigger significant increases in somal $\left[\mathrm{Ca}^{2+}\right]_{\mathrm{i}}$ in young and aged CA1 neurons, either via electrical stimulation, as reported previously (Gant et al., 2006; Thibault et al., 2001), or using pharmacological stimulation, as in the present study. Although resting $\left[\mathrm{Ca}^{2+}\right]_{\mathrm{i}}$ is not significantly changed with advancing age (Gant et al., 2006; Thibault et al., 2001), repetitive synaptic stimulation, elicits a larger peak and integrated $\left[\mathrm{Ca}^{2+}\right]_{\mathrm{i}}$ response in middle-aged (12-14 months) and aged (23 months) relative to younger adult rats (4-10 months) and this age effect is reversed by blocking RyRs, preventing the release ICS in response to $\mathrm{Ca}^{2+}$ entering via membrane bound sources (Gant et al., 2006). What's more, this larger $\mathrm{Ca}^{2+}$ response is inversely related to frequency facilitation, a form of short-term synaptic plasticity (Thibault et al., 2001). Dysregulation of $\left[\mathrm{Ca}^{2+}\right]_{\mathrm{i}}$ is implicated in another aging biomarker, enhancement of the slow after hyperpolarziation 
potential (sAHP). Following hippocampal-dependent eye-blink conditioning in rabbits, this $\mathrm{Ca}^{2+}$-dependent, $\mathrm{K}^{+}$-mediated potential, which normally holds the cell in a hyperpolarized state following a burst of action potentials, is relaxed to allow enhanced neural activity; but this potential remains greater in CA1 neurons of aged rabbits (i.e. older than 24 months) following conditioning and limits cell excitability relative to younger animals (Disterhoft et al., 1996). More relevant to the rodent model used in the current study, elevated sAHP amplitude is associated with worse spatial learning in the Morris water maze in aged F344 rats (Tombaugh et al., 2005). Appropriately, inhibition of ICS release by RyR blockade, depletion of ICS by CPA, or chelation of intracellular $\mathrm{Ca}^{2+}$ with thapsigargin, leads to the selective induction of LTP following peri-threshold stimulation in slices from aged, but not young, F344 rats by lowering the AHP and enhancing synaptic transmission via NMDARs (Kumar and Foster, 2004). Lastly, systemic administration of BAPTA-AM, a cell permeant $\mathrm{Ca}^{2+}$ chelator, will improve spatial learning in aged F344 rats performing a distributed training version of the Morris water maze whereas BAPTA-AM has no effect on the performance of young rats (Tonkikh et al., 2006). Collectively, these studies demonstrate that dysregulation of evoked intracellular $\mathrm{Ca}^{2+}$ is a reliable marker of aging in CA1 neurons that is detrimental to neural modifications necessary for learning and memory.

The use of selective compounds that signal via receptors linked to PI-hydrolysis is critical when evaluating the significance the $\mathrm{Ca}^{2+}$ imaging results reported in this study. Prior studies that examined the application of IP3 to rat hippocampal microsomes (Burnett et al., 1990) or mouse cortical slices (Stutzmann et al., 2006) did not reveal differences in $\mathrm{Ca}^{2+}$ release between samples prepared from young adult and older subjects. However, the current data support a hypothesis that changes to upstream signaling, such as altered receptor:G-protein coupling, will limit the ability of PLC $\beta 1$ to form IP3 in response to GPCR activation. Thus, while synaptic stimulation induces a larger $\mathrm{Ca}^{2+}$ response in aged rats (Gant et al., 2006), the current study shows decreased peak oxotremorine-M stimulated $\mathrm{Ca}^{2+}$ and similar peak $\mathrm{Ca}^{2+}$ after DHPG application, although the integrated response in the latter experiment tended to be greater in aged cells, suggesting differential recruitment of $\mathrm{Ca}^{2+}$ sources in a pattern distinct from that elicited by repetitive synaptic stimulation. Even though M1 and Group I mGluRs couple to the $\mathrm{Ga}_{\mathrm{q} / 11}$ subclass of G-proteins, application of oxotremorine-M and DHPG produced different results within the present study, underscoring the importance of post-synaptic scaffolds and other protein:protein interactions that confer unique, receptor-specific signaling pathways that support synaptic plasticity (Dickinson et al., 2009; Jo et al., 2010; Ménard and Quirion, 2012; Volk et al., 2007). However, the design of the current study did not pharmacologically isolate the GPCR$\mathrm{Ga}_{\mathrm{q} / 11 \text {-PLC } \beta 1-I P 3 R}$ pathway; synaptic release and post-synaptic membrane depolarization certainly activated membrane-bound $\mathrm{Ca}^{2+}$ channels and RyRs. Future studies will need to employ additional manipulations to block basal synaptic transmission, membrane-bound $\mathrm{Ca}^{2+}$ sources and RyRs to achieve better isolation of this pathway while delivering compounds that more precisely localize impaired signaling steps. In addition, techniques to examine changes in dendrites would be appropriate as IP3R density is greatest in this cellular compartment (Fitzpatrick et al., 2009) and responses may differ between dendrites and soma.

Although implicated in this study, it is unclear whether or how the increased basal activity of $\mathrm{Ga}_{\mathrm{q} / 11}$ observed in the aged hippocampus may account for any of the other changes seen in this and similar studies of brain aging (i.e. changes to downstream effectors and $\mathrm{Ca}^{2+}$ dyshomeostasis). Notably, virally induced expression of a constitutively active $\mathrm{Ga}_{\mathrm{q}}$ mutant protein, $\mathrm{Ga}_{\mathrm{q}}(\mathrm{Q} 209 \mathrm{~L})$, in $\mathrm{L} \beta \mathrm{T} 2$ pituitary cells leads to a specific decrease in PLC $\beta 1$ expression but increased stimulated calcium influx through VGCCs without altering endogenous receptor or G-protein expression (Liu et al., 2005). As mentioned previously, aging also decreases hippocampal PLC $\beta 1$ expression without similar changes to GPCR or 
G-protein levels (Chouinard et al., 1995; Nicolle et al., 1999; Zhang et al., 2007) while potentiating responses from VGCCs (Campbell et al., 1996; Thibault and Landfield, 1996; Thibault et al., 2001). Importantly, $\mathrm{Ga}_{\mathrm{q}}(\mathrm{Q} 209 \mathrm{~L})$-enhanced calcium influx via VGCCs was associated with decreased downstream cellular responses due to impaired activation via the mitogen-activated protein kinase pathway (Liu et al., 2005), a phenotype also observed in the aged hippocampus that is tightly linked with normal learning and memory (Blum et al., 1999; Ménard and Quirion, 2012). While highly speculative, it is provocative to hypothesize that elevated basal activity of this specific Ga-protein is a central parameter that links maladaptive changes to neural biochemistry and physiology and ultimately impaired cognition.

\section{Conclusion}

The current data demonstrate that aging selectively modulates the functions of a particular subtype of Ga-protein with implications for downstream signaling. Normal aging is associated with increased basal activity of $\mathrm{Ga}_{\mathrm{q} / 11}$, the G-protein subtype that links the activation of GPCRs, including M1 mAChRs and Group I mGluRs, to PI-turnover and $\mathrm{Ca}^{2+}$ release but even within this subclass of receptors, compensatory signaling may arise in a system-specific fashion. However, aging is also broadly associated with a shift in the relative contributions of $\mathrm{Ca}^{2+}$ sources following pharmacologic stimulation. Thus, additional experimentation is necessary to outline a role for constitutive activity of $\mathrm{Ga}_{\mathrm{q} / 11}$ in the modulation of neural signaling as well as to determine how an upstream gain-in-function will elicit paradoxical decreases in downstream responses following receptor stimulation. As much interest already focuses on the therapeutic potential of this class of receptors, such information will be vital to develop novel therapies that can beneficially modulate specific GPCR-initiated signaling pathways to favor the induction of LTP over LTD while correcting $\mathrm{Ca}^{2+}$ dyshomeostasis in aged neurons.

\section{Supplementary Material}

Refer to Web version on PubMed Central for supplementary material.

\section{Acknowledgments}

This work was supported by NIH grants F31-AG038266 to JAM, R01-AG020572 to MMN, R01-DA03690 to ACH and R01-DA007625 to SAD. The authors thank Dennis O. Rookwood, Jr., for technical assistance in the behavioral training of rats used in this study.

\section{References}

Attucci S, Clodfelter GV, Thibault O, Staton J, Moroni F, Landfield PW, Porter NM. Group I metabotropic glutamate receptor inhibition selectively blocks a prolonged $\mathrm{Ca} 2+$ elevation associated with age-dependent excitotoxicity. Neuroscience. 2002; 112:183-194. [PubMed: 12044483]

Aubert I, Rowe W, Meaney MJ, Gauthier S, Quirion R. Cholinergic markers in aged cognitively impaired long-evans rats. Neuroscience. 1995; 67:277-292. [PubMed: 7675169]

Ayyagari PV, Gerber M, Joseph JA, Crews FT. Uncoupling of muscarinic cholinergic phosphoinositide signals in senescent cerebral cortical and hippocampal membranes. Neurochem Int. 1998; 32:107-115. [PubMed: 9460709]

Bakker A, Krauss GL, Albert MS, Speck CL, Jones LR, Stark CE, Yassa MA, Bassett SS, Shelton AL, Gallagher M. Reduction of Hippocampal Hyperactivity Improves Cognition in Amnestic Mild Cognitive Impairment. Neuron. 2012; 74:467-474. [PubMed: 22578498] 
Bañuelos C, LaSarge CL, McQuail JA, Hartman JJ, Gilbert RJ, Ormerod BK, Bizon JL. Age-related changes in rostral basal forebrain cholinergic and GABAergic projection neurons: relationship with spatial impairment. Neurobiol Aging. 2013; 34:845-862. [PubMed: 22817834]

Barnes C, Rao G, Shen J. Age-Related Decrease in the N-Methyl-d-AspartateR-Mediated Excitatory Postsynaptic Potential in Hippocampal Region CA1. Neurobiol Aging. 1997; 18:445-452. [PubMed: 9330977]

Bizon JL, LaSarge CL, Montgomery KS, McDermott AN, Setlow B, Griffith WH. Spatial reference and working memory across the lifespan of male Fischer 344 rats. Neurobiol Aging. 2009; 30:646655. [PubMed: 17889407]

Blum S, Moore AN, Adams F, Dash PK. A Mitogen-Activated Protein Kinase Cascade in the CA1/ CA2 Subfield of the Dorsal Hippocampus Is Essential for Long-Term Spatial Memory. J Neurosci. 1999; 19:3535-3544. [PubMed: 10212313]

Bodhinathan K, Kumar A, Foster TC. Intracellular Redox State Alters NMDA Receptor Response During Aging Through Ca2+/Calmodulin-Dependent Protein Kinase II. J Neurosci. 2010; 30:19141924. [PubMed: 20130200]

Bordi F, Ugolini A. Group I metabotropic glutamate receptors: implications for brain diseases. Prog Neurobiol. 1999; 59:55-79. [PubMed: 10416961]

Boric K, Muñoz P, Gallagher M, Kirkwood A. Potential Adaptive Function for Altered Long-Term Potentiation Mechanisms in Aging Hippocampus. J Neurosci. 2008; 28:8034-8039. [PubMed: 18685028]

Burke SN, Barnes CA. Senescent synapses and hippocampal circuit dynamics. Trends Neurosci. 2010; 33:153-161. [PubMed: 20071039]

Burnett DM, Daniell LC, Zahniser NR. Decreased efficacy of inositol 1,4,5-trisphosphate to elicit calcium mobilization from cerebrocortical microsomes of aged rats. Mol Pharmacol. 1990; 37:566-571. [PubMed: 2157962]

Caccamo A, Oddo S, Billings LM, Green KN, Martinez-Coria H, Fisher A, LaFerla FM. M1 Receptors Play a Central Role in Modulating AD-like Pathology in Transgenic Mice. Neuron. 2006; 49:671682. [PubMed: 16504943]

Campbell LW, Hao SY, Thibault O, Blalock EM, Landfield PW. Aging Changes in Voltage-Gated Calcium Currents in Hippocampal CA1 Neurons. J Neurosci. 1996; 16:6286-6295. [PubMed: 8815908]

Caulfield MP, Birdsall NJM. International Union of Pharmacology. XVII. Classification of Muscarinic Acetylcholine Receptors. Pharmacol Rev. 1998; 50:279-290. [PubMed: 9647869]

Chalifoux JR, Carter AG. GABAB receptor modulation of synaptic function. Curr Opin Neurobiol. 2011; 21:339-344. [PubMed: 21376567]

Chouinard ML, Gallagher M, Yasuda RP, Wolfe BB, McKinney M. Hippocampal muscarinic receptor function in spatial learning-impaired aged rats. Neurobiol Aging. 1995; 16:955-963. [PubMed: 8622787]

Delapp NW, McKinzie JH, Sawyer BD, Vandergriff A, Falcone J, McClure D, Felder CC. Determination of [35S]Guanosine-5'-O-(3-thio)Triphosphate Binding Mediated by Cholinergic Muscarinic Receptors in Membranes from Chinese Hamster Ovary Cells and Rat Striatum Using an Anti-G Protein Scintillation Proximity Assay. J Pharmacol Exp Ther. 1999; 289:946-955. [PubMed: 10215674]

Dickinson BA, Jo J, Seok H, Son GH, Whitcomb DJ, Davies CH, Sheng M, Collingridge GL, Cho K. A novel mechanism of hippocampal LTD involving muscarinic receptor-triggered interactions between AMPARs, GRIP and liprin-a. Mol Brain. 2009; 2:18. [PubMed: 19534762]

Disterhoft JF, Thompson LT, Moyer JR Jr, Mogul DJ. Calcium-dependent after hyperpolarization and learning in young and aging hippocampus. Life Sci. 1996; 59:413-420. [PubMed: 8761329]

Fitzpatrick JS, Hagenston AM, Hertle DN, Gipson KE, Bertetto-D’Angelo L, Yeckel MF. Inositol-1,4,5-trisphosphate receptor-mediated $\mathrm{Ca} 2+$ waves in pyramidal neuron dendrites propagate through hot spots and cold spots. J Physiol. 2009; 587:1439-1459. [PubMed: 19204047]

Foster TC, Kumar A. Susceptibility to induction of long-term depression is associated with impaired memory in aged Fischer 344 rats. Neurobiology of Learning and Memory. 2007; 87:522-535. [PubMed: 17276704] 
Fritschy JM, Meskenaite V, Weinmann O, Honer M, Benke D, Mohler H. GABAB-receptor splice variants GB1a and GB1b in rat brain: developmental regulation, cellular distribution and extrasynaptic localization. Eur J Neurosci. 1999; 11:761-768. [PubMed: 10103070]

Froestl W, Gallagher M, Jenkins H, Madrid A, Melcher T, Teichman S, Mondadori CG, Pearlman R. SGS742: the first GABAB receptor antagonist in clinical trials. Biochem Pharmacol. 2004; 68:1479-1487. [PubMed: 15451390]

Gallagher M, Burwell R, Burchinal MR. Severity of spatial learning impairment in aging: Development of a learning index for performance in the Morris water maze. Behav Neurosci. 1993; 107:618-626. [PubMed: 8397866]

Gant JC, Sama MM, Landfield PW, Thibault O. Early and Simultaneous Emergence of Multiple Hippocampal Biomarkers of Aging Is Mediated by Ca2+-Induced Ca2+ Release. J Neurosci. 2006; 26:3482-3490. [PubMed: 16571755]

Goussakov I, Miller MB, Stutzmann GE. NMDA-Mediated Ca2+ Influx Drives Aberrant Ryanodine Receptor Activation in Dendrites of Young Alzheimer's Disease Mice. J Neurosci. 2010; 30:12128-12137. [PubMed: 20826675]

Greenwood AF, Powers RE, Jope RS. Phosphoinositide hydrolysis, Gaq, phospholipase C, and protein kinase $\mathrm{C}$ in post mortem human brain: Effects of post mortem interval, subject age, and alzheimer's disease. Neuroscience. 1995; 69:125-138. [PubMed: 8637611]

Hampson RE, Miller F, Palchik G, Deadwyler SA. Cannabinoid receptor activation modifies NMDA receptor mediated release of intracellular calcium: Implications for endocannabinoid control of hippocampal neural plasticity. Neuropharmacology. 2011; 60:944-952. [PubMed: 21288475]

Jo J, Son GH, Winters BL, Kim MJ, Whitcomb DJ, Dickinson BA, Lee YB, Futai K, Amici M, Sheng M, Collingridge GL, Cho K. Muscarinic receptors induce LTD of NMDAR EPSCs via a mechanism involving hippocalcin, AP2 and PSD-95. Nat Neurosci. 2010; 13:1216-1224. [PubMed: 20852624]

Jones CK, Brady AE, Davis AA, Xiang Z, Bubser M, Tantawy MN, Kane AS, Bridges TM, Kennedy JP, Bradley SR, Peterson TE, Ansari MS, Baldwin RM, Kessler RM, Deutch AY, Lah JJ, Levey AI, Lindsley CW, Conn PJ. Novel Selective Allosteric Activator of the M1 Muscarinic Acetylcholine Receptor Regulates Amyloid Processing and Produces Antipsychotic-Like Activity in Rats. J Neurosci. 2008; 28:10422-10433. [PubMed: 18842902]

Jope RS, Song L, Powers RE. Cholinergic activation of phosphoinositide signaling is impaired in Alzheimer's disease brain. Neurobiol Aging. 1997; 18:111-120. [PubMed: 8983039]

Koh MT, Haberman RP, Foti S, McCown TJ, Gallagher M. Treatment Strategies Targeting Excess Hippocampal Activity Benefit Aged Rats with Cognitive Impairment. Neuropsychopharmacology. 2010; 35:1016-1025. [PubMed: 20032967]

Kumar A. Carbachol-Induced Long-Term Synaptic Depression Is Enhanced During Senescence at Hippocampal CA3-CA1 Synapses. J Neurophysiol. 2010; 104:607-616. [PubMed: 20505129]

Kumar A, Foster TC. Enhanced Long-Term Potentiation During Aging Is Masked by Processes Involving Intracellular Calcium Stores. J Neurophysiol. 2004; 91:2437-2444. [PubMed: 14762159]

Kumar A, Foster TC. Intracellular calcium stores contribute to increased susceptibility to LTD induction during aging. Brain Res. 2005; 1031:125-128. [PubMed: 15621020]

Kumar A, Foster TC. Shift in Induction Mechanisms Underlies an Age-Dependent Increase in DHPGInduced Synaptic Depression at CA3-CA1 Synapses. J Neurophysiol. 2007; 98:2729-2736. [PubMed: 17898145]

Lasarge CL, Bañuelos C, Mayse JD, Bizon JL. Blockade of GABA(B) receptors completely reverses age-related learning impairment. Neuroscience. 2009; 164:941-947. [PubMed: 19723562]

Lee HK, Min SS, Gallagher M, Kirkwood A. NMDA receptor-independent long-term depression correlates with successful aging in rats. Nat Neurosci. 2005; 8:1657-1659. [PubMed: 16286930]

Liu F, Ruiz MS, Austin DA, Webster NJG. Constitutively Active Gq Impairs Gonadotropin-Releasing Hormone-Induced Intracellular Signaling and Luteinizing Hormone Secretion in L $\beta$ T2 Cells. Mol Endocrinol. 2005; 19:2074-2085. [PubMed: 15878957] 
Mannaioni G, Marino MJ, Valenti O, Traynelis SF, Conn PJ. Metabotropic Glutamate Receptors 1 and 5 Differentially Regulate CA1 Pyramidal Cell Function. J Neurosci. 2001; 21:5925-5934. [PubMed: 11487615]

McQuail JA, Bañuelos C, LaSarge CL, Nicolle MM, Bizon JL. GABAB receptor GTP-binding is decreased in the prefrontal cortex but not the hippocampus of aged rats. Neurobiol Aging. 2012; 33:1124.e1-1124.e12. [PubMed: 22169202]

Ménard C, Quirion R. Successful Cognitive Aging in Rats: A Role for mGluR5 Glutamate Receptors, Homer 1 Proteins and Downstream Signaling Pathways. PLoS ONE. 2012; 7 :e28666. [PubMed: 22238580]

Milligan G. Principles: Extending the utility of [35S]GTP $\gamma$ S binding assays. Trends Pharmacol Sci. 2003; 24:87-90. [PubMed: 12559773]

Nagarkatti N, Deshpande LS, DeLorenzo RJ. Levetiracetam Inhibits both ryanodine and IP3 receptor activated calcium induced calcium release in hippocampal neurons in culture. Neurosci Lett. 2008; 436:289-293. [PubMed: 18406528]

Nicolle M, Bizon J, Gallagher M. In vitro autoradiography of ionotropic glutamate receptors in hippocampus and striatum of aged Long-Evans rats: relationship to spatial learning. Neuroscience. 1996; 74:741-756. [PubMed: 8884770]

Nicolle MM, Colombo PJ, Gallagher M, McKinney M. Metabotropic Glutamate Receptor-Mediated Hippocampal Phosphoinositide Turnover Is Blunted in Spatial Learning-Impaired Aged Rats. J Neurosci. 1999; 19:9604-9610. [PubMed: 10531462]

Nicolle MM, Gallagher M, McKinney M. Visualization of muscarinic receptor-mediated phosphoinositide turnover in the hippocampus of young and aged, learning-impaired Long Evans rats. Hippocampus. 2001; 11:741-746. [PubMed: 11811668]

Nieves-Martinez E, Haynes K, Childers SR, Sonntag WE, Nicolle MM. Muscarinic receptor/G-protein coupling is reduced in the dorsomedial striatum of cognitively impaired aged rats. Behav Brain Res. 2012; 227:258-264. [PubMed: 22085876]

Oulès B, Prete DD, Greco B, Zhang X, Lauritzen I, Sevalle J, Moreno S, Paterlini-Bréchot P, Trebak M, Checler F, Benfenati F, Chami M. Ryanodine Receptor Blockade Reduces Amyloid- $\beta$ Load and Memory Impairments in Tg2576 Mouse Model of Alzheimer Disease. J Neurosci. 2012; 32:11820-11834. [PubMed: 22915123]

Parent A, Rowe W, Meaney MJ, Quirion R. Increased production of inositol phosphates and diacylglycerol in aged cognitively impaired rats after stimulation of muscarinic, metabotropicglutamate and endothelin receptors. J Pharmacol Exp Ther. 1995; 272:1110-1116. [PubMed: 7891323]

Porter AC, Bymaster FP, DeLapp NW, Yamada M, Wess J, Hamilton SE, Nathanson NM, Felder CC. M1 muscarinic receptor signaling in mouse hippocampus and cortex. Brain Res. 2002; 944:82-89. [PubMed: 12106668]

Potier B, Poindessous-Jazat F, Dutar P, Billard J. NMDA receptor activation in the aged rat hippocampus. Exp Gerontol. 2000; 35:1185-1199. [PubMed: 11113601]

Quirion R, Wilson A, Rowe W, Aubert I, Richard J, Doods H, Parent A, White N, Meaney MJ. Facilitation of Acetylcholine Release and Cognitive Performance by an M(2)-Muscarinic Receptor Antagonist in Aged Memory-Impaired. J Neurosci. 1995; 15:1455-1462. [PubMed: 7869110]

Reisberg B, Doody R, Stöffler A, Schmitt F, Ferris S, Möbius HJ. Memantine in moderate-to-severe Alzheimer's disease. N Engl J Med. 2003; 348:1333-1341. [PubMed: 12672860]

Robbins MJ, Calver AR, Filippov AK, Hirst WD, Russell RB, Wood MD, Nasir S, Couve A, Brown DA, Moss SJ, Pangalos MN. GABAB2 Is Essential for G-Protein Coupling of the GABAB Receptor Heterodimer. J Neurosci. 2001; 21:8043-8052. [PubMed: 11588177]

Salah-Uddin H, Thomas DR, Davies CH, Hagan JJ, Wood MD, Watson JM, Challiss RAJ. Pharmacological Assessment of M1 Muscarinic Acetylcholine Receptor-Gq/11 Protein Coupling in Membranes Prepared from Postmortem Human Brain Tissue. J Pharmacol Exp Ther. 2008; 325:869-874. [PubMed: 18322150]

Shi L, Adams MM, Linville MC, Newton IG, Forbes ME, Long AB, Riddle DR, Brunso-Bechtold JK. Caloric restriction eliminates the aging-related decline in NMDA and AMPA receptor subunits in 
the rat hippocampus and induces homeostasis. Exp Neurol. 2007; 206:70-79. [PubMed: 17490652]

Smith TD, Gallagher M, Leslie FM. Cholinergic binding sites in rat brain: Analysis by age and cognitive status. Neurobiol Aging. 1995; 16:161-173. [PubMed: 7777134]

Soler F, Plenge-Tellechea F, Fortea I, Fernandez-Belda F. Cyclopiazonic Acid Effect on Ca2+Dependent Conformational States of the Sarcoplasmic Reticulum ATPase. Implication for the Enzyme Turnover. Biochemistry. 1998; 37:4266-4274. [PubMed: 9521749]

Stanley DP, Shetty AK. Aging in the rat hippocampus is associated with widespread reductions in the number of glutamate decarboxylase-67 positive interneurons but not interneuron degeneration. $\mathrm{J}$ Neurochem. 2004; 89:204-216. [PubMed: 15030405]

Stutzmann GE, Smith I, Caccamo A, Oddo S, LaFerla FM, Parker I. Enhanced Ryanodine Receptor Recruitment Contributes to Ca2+ Disruptions in Young, Adult, and Aged Alzheimer's Disease Mice. J Neurosci. 2006; 26:5180-5189. [PubMed: 16687509]

Tandon P, Mundy WR, Ali SF, Nanry K, Rogers BC, Tilson HA. Age-dependent changes in receptorstimulated phosphoinositide turnover in the rat hippocampus. Pharmacol Biochem Behav. 1991; 38:861-867. [PubMed: 1651520]

Thibault O, Hadley R, Landfield PW. Elevated Postsynaptic [Ca2+]i and L-Type Calcium Channel Activity in Aged Hippocampal Neurons: Relationship to Impaired Synaptic Plasticity. J Neurosci. 2001; 21:9744-9756. [PubMed: 11739583]

Thibault O, Landfield PW. Increase in single L-type calcium channels in hippocampal neurons during aging. Science. 1996; 272:1017. [PubMed: 8638124]

Tombaugh GC, Rowe WB, Rose GM. The Slow Afterhyperpolarization in Hippocampal CA1 Neurons Covaries with Spatial Learning Ability in Aged Fisher 344 Rats. J Neurosci. 2005; 25:2609-2616. [PubMed: 15758171]

Tonkikh A, Janus C, El-Beheiry H, Pennefather PS, Samoilova M, McDonald P, Ouanounou A, Carlen PL. Calcium chelation improves spatial learning and synaptic plasticity in aged rats. Exp Neurol. 2006; 197:291-300. [PubMed: 16039651]

Volbracht C, Van Beek J, Zhu C, Blomgren K, Leist M. Neuroprotective properties of memantine in different in vitro and in vivo models of excitotoxicity. Eur J Neurosci. 2006; 23:2611-2622. [PubMed: 16817864]

Volk LJ, Pfeiffer BE, Gibson JR, Huber KM. Multiple Gq-Coupled Receptors Converge on a Common Protein Synthesis-Dependent Long-Term Depression That Is Affected in Fragile X Syndrome Mental Retardation. J Neurosci. 2007; 27:11624-11634. [PubMed: 17959805]

Wenk GL, Barnes CA. Regional changes in the hippocampal density of AMPA and NMDA receptors across the lifespan of the rat. Brain Res. 2000; 885:1-5. [PubMed: 11121523]

Ypsilanti AR, Girão da Cruz MT, Burgess A, Aubert I. The length of hippocampal cholinergic fibers is reduced in the aging brain. Neurobiol Aging. 2008; 29:1666-1679. [PubMed: 17507114]

Zhang HY, Watson ML, Gallagher M, Nicolle MM. Muscarinic receptor-mediated GTP-Eu binding in the hippocampus and prefrontal cortex is correlated with spatial memory impairment in aged rats. Neurobiol Aging. 2007; 28:619-626. [PubMed: 16600436] 


\section{Highlights}

- This study uses a naturally occurring model of cognitive aging in the rat

- Basal GTP $\gamma \mathrm{S}$-binding to $\mathrm{Ga}_{\mathrm{q} / 11}$ is elevated in the aged hippocampus

- Muscarinic stimulation of $\left[\mathrm{Ca}^{2+}\right]_{\mathrm{i}}$ is blunted in aged hippocampus

- GPCR stimulation of $\left[\mathrm{Ca}^{2+}\right]_{\mathrm{i}}$ is more dependent on ICS in aged hippocampus

- These effects of age are not related to spatial learning impairment 

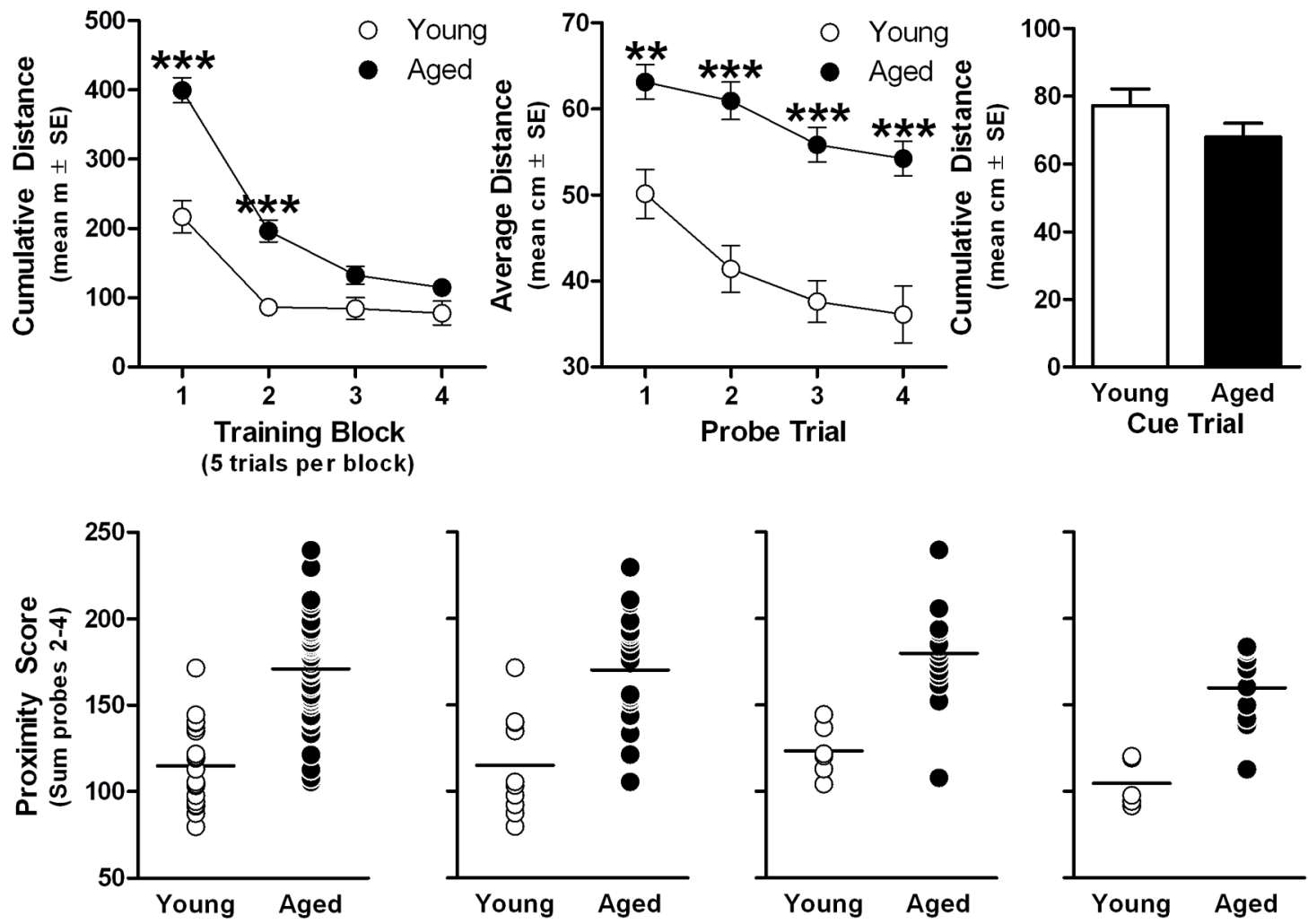

Fig 1. Performance of young and aged rats in the Morris water maze

Young ( 6 months; $n=21$ ) and aged ( 24 months; $n=47)$ rats were trained on a hiddenplatform/place-learning version of the Morris water maze organized into 4 blocks that each included 5 training trials (A) and a single probe trial (B) administered at the end of each training block. After the end of place training, rats received a single block of six visibleplatform/cue-training trials (C). Probe trial measures were summed to compute "proximity scores" to characterize the range of individual performance differences within this study population (D; horizontal line denotes mean of each group). Proximity scores of each cohort used for GTP $\gamma$ S-binding ( $n=10$ young, $n=22$ aged; E), oxotremorine-M-stimulated $\left[\mathrm{Ca}^{2+}\right]_{\mathrm{i}}$ ( $n=6$ young, $n=15$ aged; F) or DHPG-stimulated $\left[\mathrm{Ca}^{2+}\right]_{\mathrm{i}}(n=5$ young, $n=10$ aged; $\mathrm{G})$. $* * p<0.01$ and $* * * p<0.001$ vs. young according to Bonferroni post hoctest (A\&B). *** $p<0.001$ vs. young by independent samples $t$-test (D-G). 
A

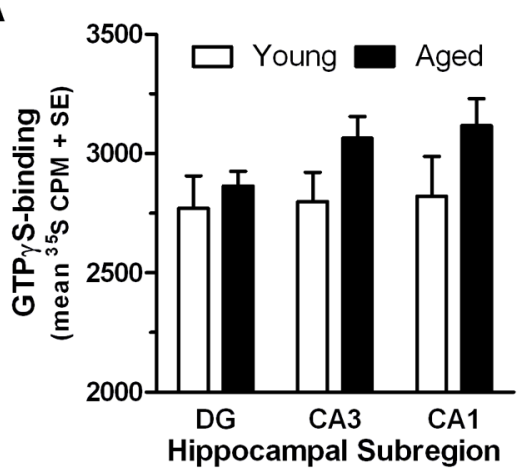

D

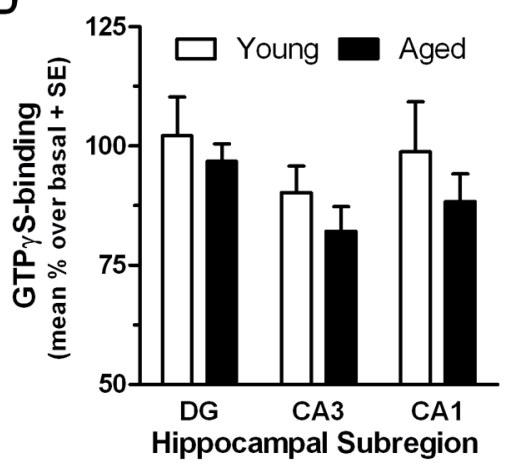

B

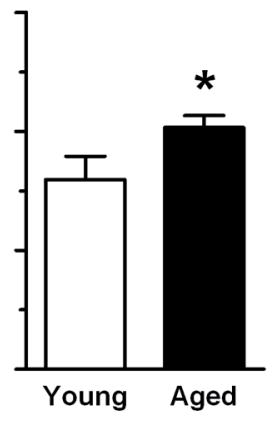

E

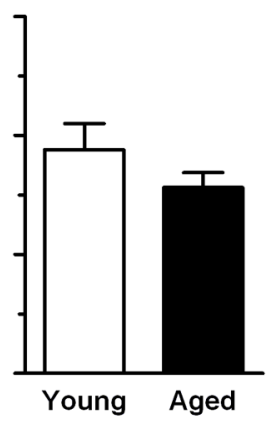

C

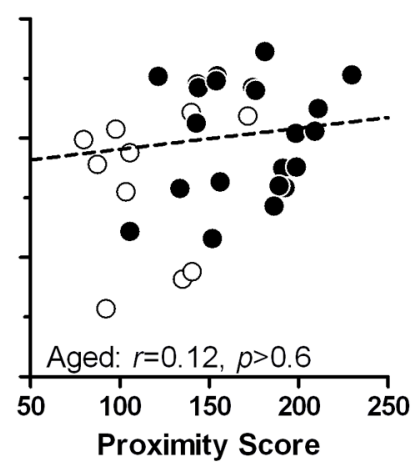

$\mathbf{F}$

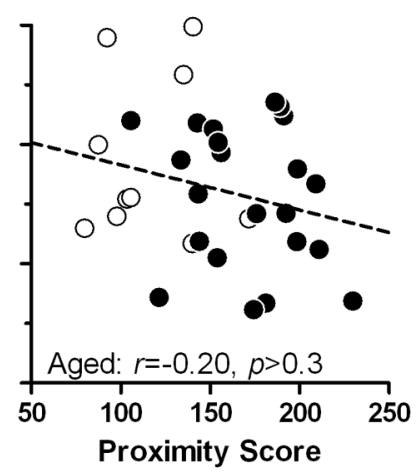

Fig 2. GTP $\gamma \mathrm{S}$-binding to $\mathrm{Ga}_{\mathrm{q} / 11}$ in the hippocampus of young and aged rats

$\left[{ }^{35} \mathrm{~S}\right] \mathrm{GTP} \gamma \mathrm{S}$-binding assay was combined with an antibody-capture scintillation proximity

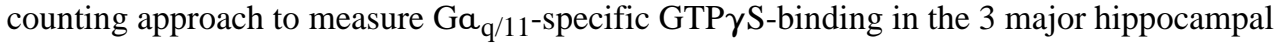
subregions ( $n=10$ young, $n=22$ aged; A and D). Basal (agonist-free) GTP $\gamma \mathrm{S}$-binding to $\mathrm{Ga}_{\mathrm{q} / 11}$ (A) was averaged for all 3 subregions ( $\mathrm{B} ;{ }^{*} p<0.05$ vs. young by independent samples $t$-test) and subsequently tested for association with proximity scores $(\mathrm{C}$; solid line denotes significant trend line; INSET: $r$ and $p$-values for aged group). GTP $\gamma \mathrm{S}$-binding to $\mathrm{Ga}_{\mathrm{q} / 11}$ stimulated by $100 \mu \mathrm{M}$ oxotremorine-M (D) was similarly averaged across all 3 subregions (E) and tested for association with proximity scores (F; dashed line denotes nonsignificant trend line; INSET: $r$ and $p$-values for aged group). 
A

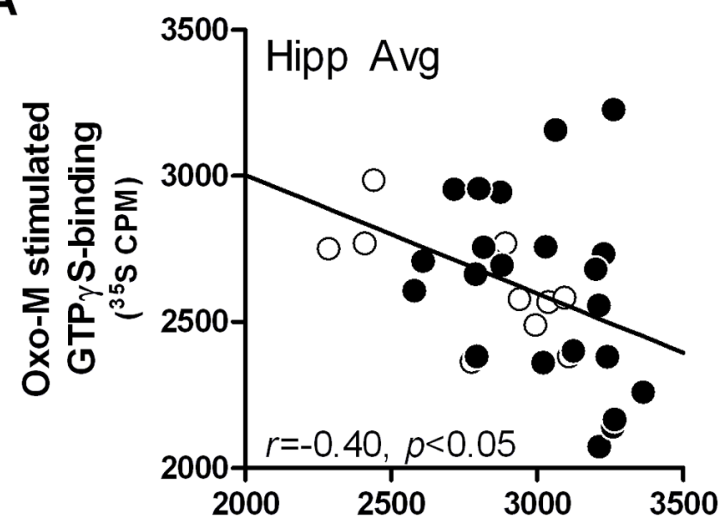

C

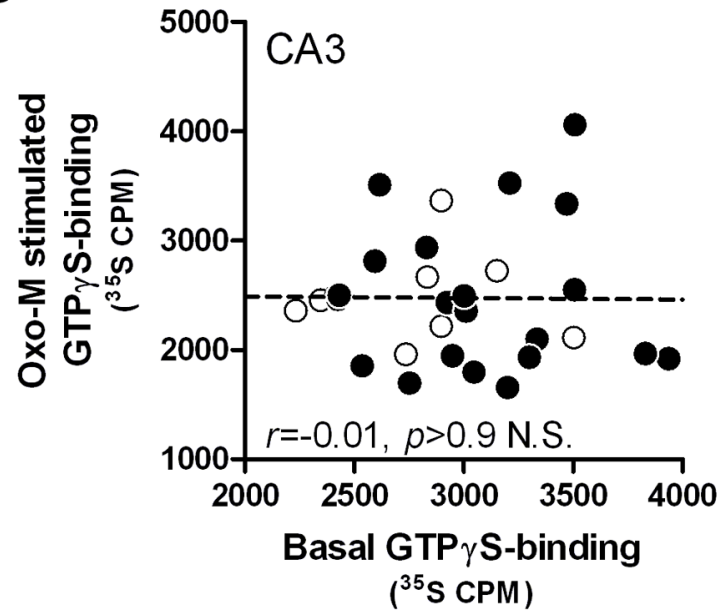

B

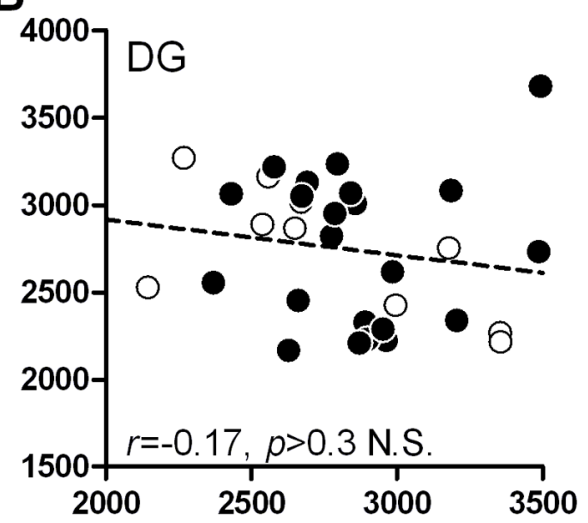

D

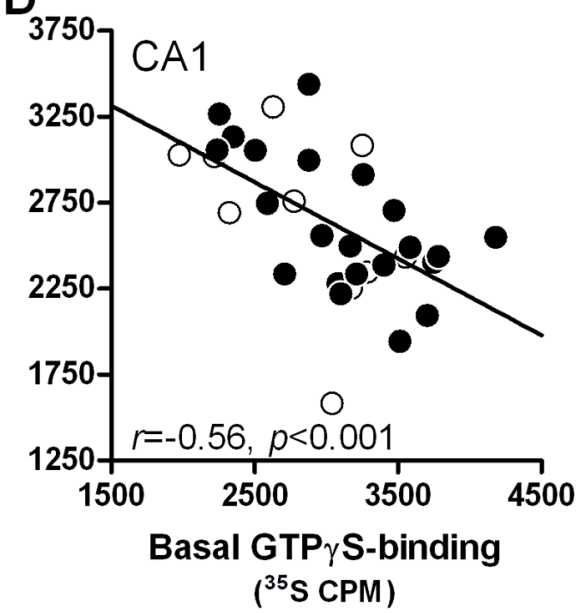

Fig. 3. Basal and oxotremorine-M stimulated $\mathrm{GTP} \gamma \mathrm{S}$-binding to $\mathrm{Ga}_{\mathrm{q} / 11}$ are inversely correlated in the hippocampus of young and aged rats

Basal and oxotremorine-M $\left[{ }^{35} \mathrm{~S}\right] \mathrm{GTP} \gamma \mathrm{S}$-binding were measured for correlation in the average of 3 hippocampal subregions (A), DG (B), CA3 (C) and CA1 (D). Solid lines denote significant trend lines and dashed lines denote non-significant trend line; INSET: $r$ and $p$-values for young $(n=10)$ and aged $(n=22)$ group tested together. 
A

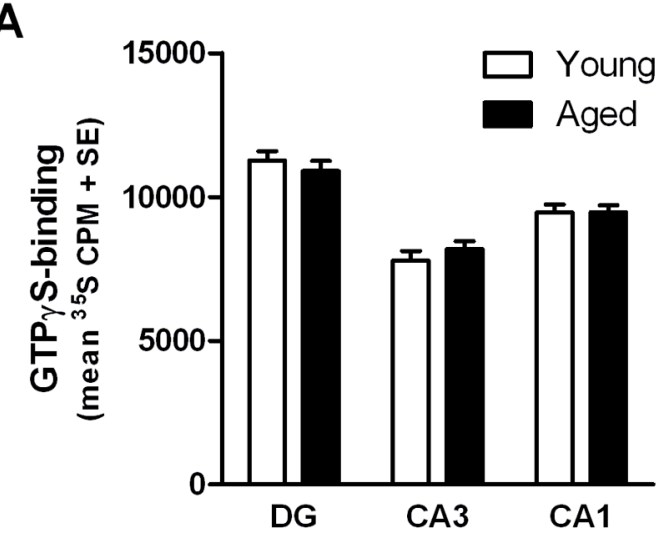

B

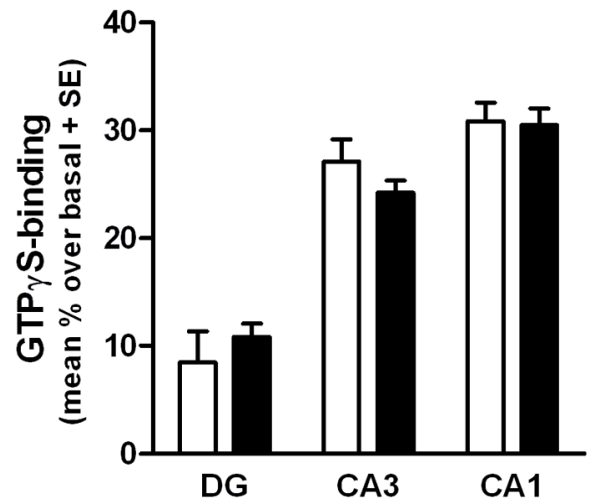

C

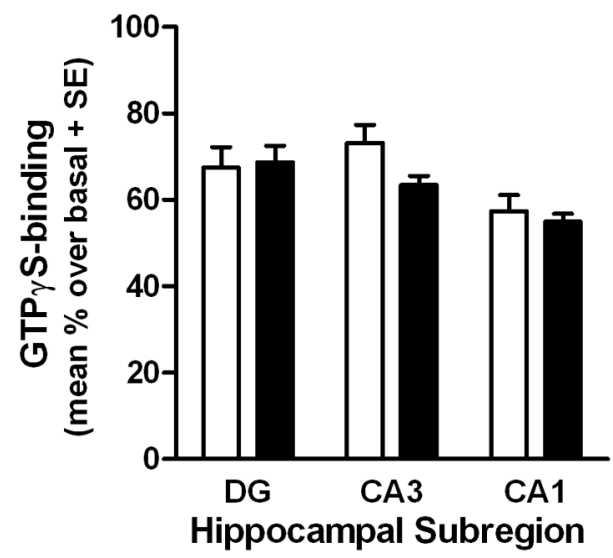

Fig. 4. GTP $\gamma \mathrm{S}$-binding to $\mathrm{Ga}_{0}$ in the hippocampus of young and aged rats $\left[{ }^{35} \mathrm{~S}\right]$ GTP $\gamma \mathrm{S}$-binding assay was combined with an antibody-capture scintillation proximity counting approach to measure basal activity (A) as well as GTP $\gamma \mathrm{S}$-binding to $\mathrm{Ga}_{\mathrm{o}}$ stimulated by $100 \mu \mathrm{M}$ oxotremorine-M (B) and $300 \mu \mathrm{M}$ baclofen (C) in the 3 major hippocampal subregions of young and aged rats ( $n=10$ young, $n=22$ aged; A-C). 
A

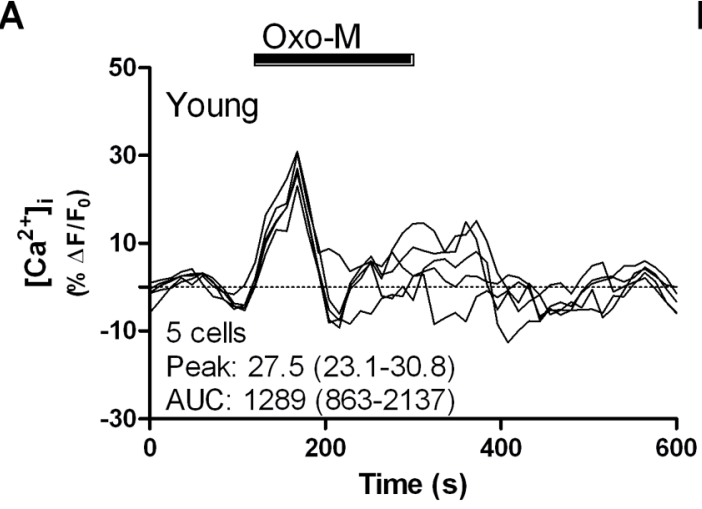

C

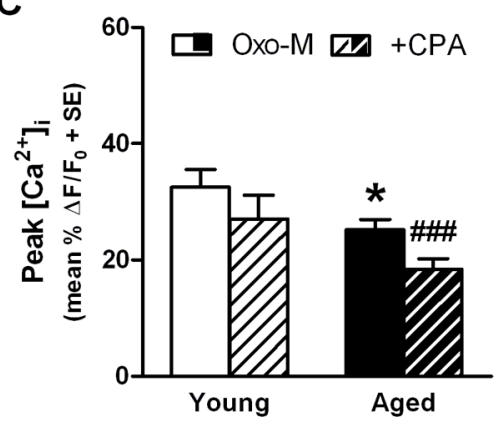

B

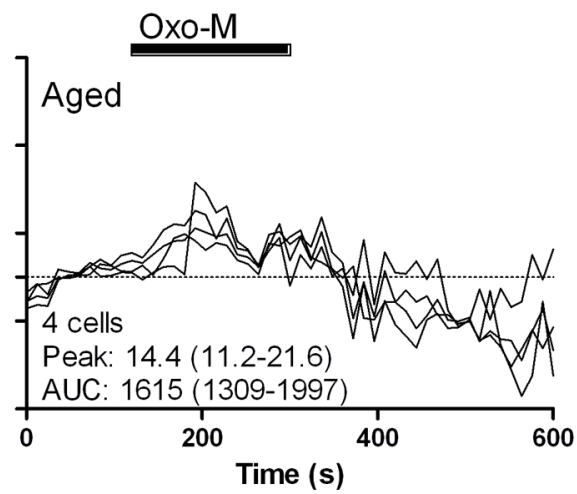

$\mathbf{F}$

D

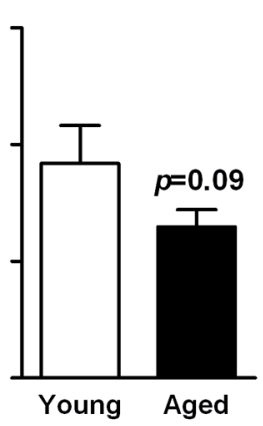

E

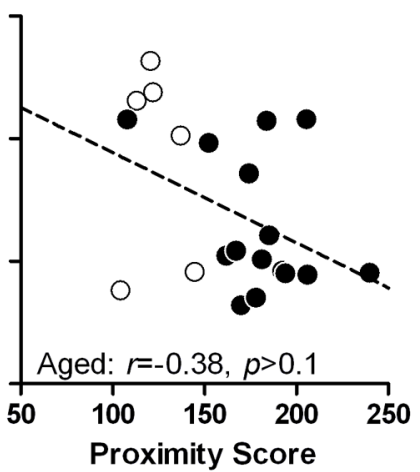

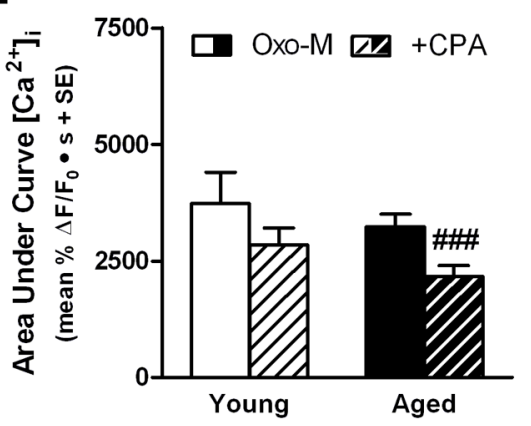

G

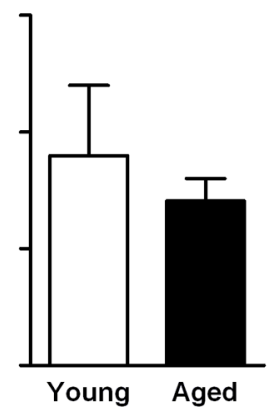

Fig. 5. Oxotremorine-M-stimulated changes to intracellular $\mathrm{Ca}^{2+}$ concentration in $\mathrm{CA1}$ of young and aged rats

Representative results of $\mathrm{Ca}^{2+}$ imaging in hippocampal slices showing time-course of changes to intracellular $\mathrm{Ca}^{2+}$ concentration stimulated by $50 \mu \mathrm{M}$ oxotremorine-M (Oxo-M) in young (A) and aged CA1 cells (B); INSET: number of cells and mean peak and area under curve (AUC), range of values is given in parentheses. Peak change in intracellular $\mathrm{Ca}^{2+}$ concentration of young and aged cells $(\mathrm{C} ; n=72$ cells from young, $n=136$ cells from aged), averaged by rat ( $\mathrm{D} ; n=6$ young, $n=15$ aged) and tested for association with proximity scores (E; dashed line denotes non-significant trend line; INSET: $r$ and $p$-values for aged group). Area under curve of intracellular $\mathrm{Ca}^{2+}$ response of young and aged cells $(\mathrm{F})$ and averaged by rat $(\mathrm{G})$. Black bar in A and B denotes time period of agonist application. $* p<0.05$ vs. young according to independent-samples $t$-test; \#\#\# $p<0.001$ vs. oxotremorine$\mathrm{M}$ control according to paired-samples $t$-test. 
A

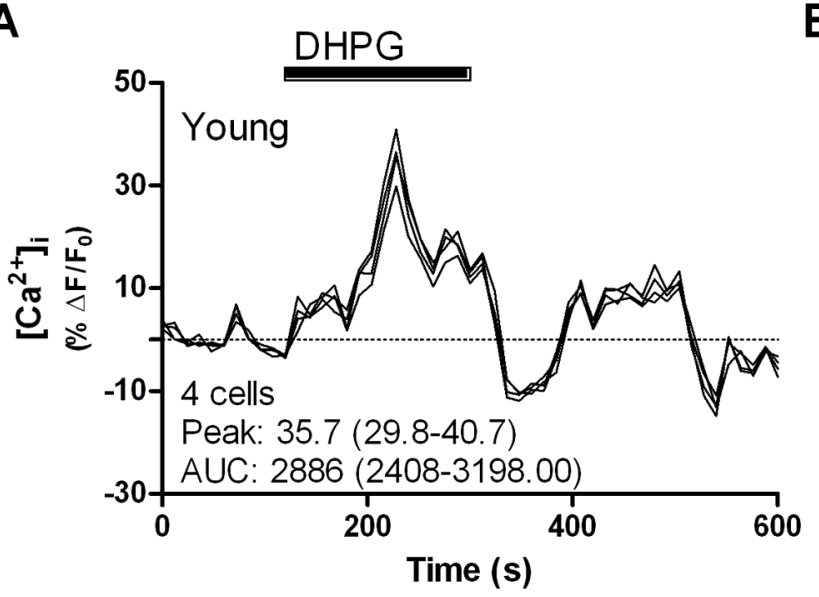

C

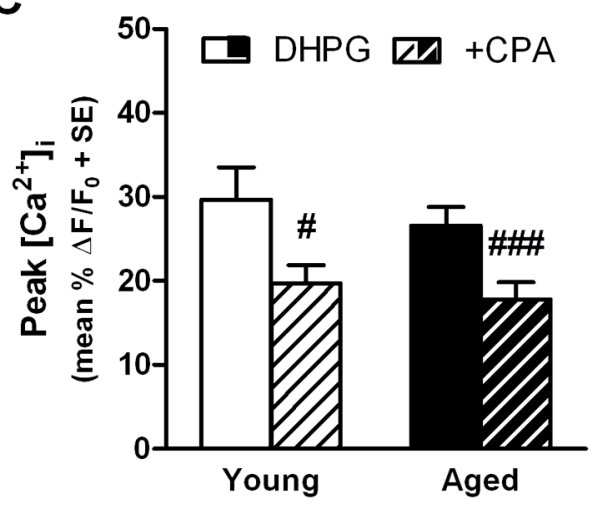

E

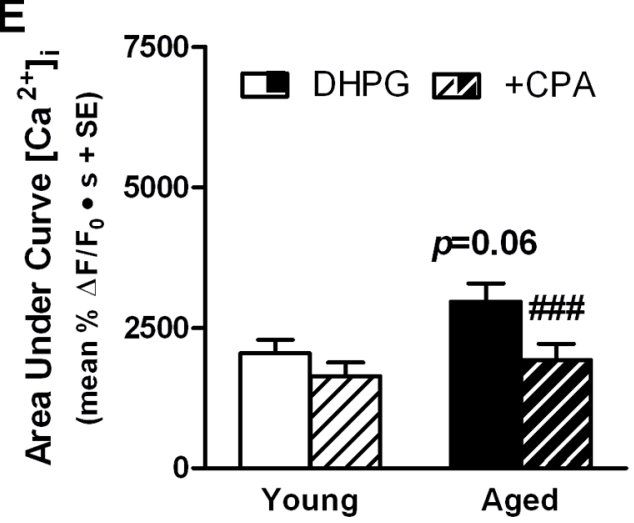

B

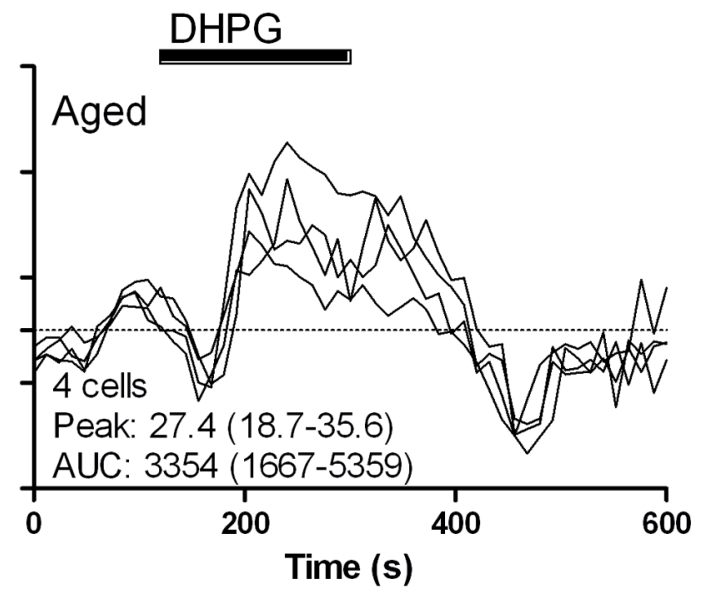

D

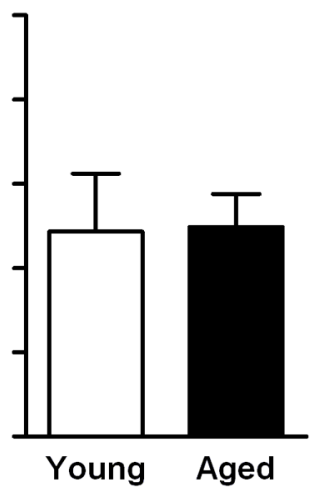

$\mathbf{F}$

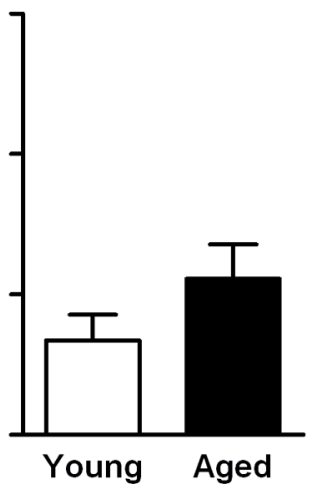

Fig 6. DHPG-stimulated changes to intracellular $\mathrm{Ca}^{2+}$ concentration in $\mathrm{CA1}$ of young and aged rats

Representative results of $\mathrm{Ca}^{2+}$ imaging showing time-course of changes to intracellular $\mathrm{Ca}^{2+}$ concentration in hippocampal slices stimulated by $50 \mu \mathrm{M}$ DHPG in young (A) and aged CA1 cells (B); INSET: number of cells and mean peak and area under curve (AUC), range of values is given in parentheses. Peak change in intracellular $\mathrm{Ca}^{2+}$ concentration of young and aged cells ( $\mathrm{C} ; n=35$ cells from aged, $n=67$ cells from young) and averaged by rat (D; $n=5$ young, $n=10$ aged). Area under curve of intracellular $\mathrm{Ca}^{2+}$ response of young and aged cells (E) and averaged by rat (F). Black bar in A and B denotes time period of agonist application. ${ }^{*} p<0.05$ vs. young according to independent-samples $t$-test; $\# p<0.05$, $\# \# \#<0.001$ vs. DHPG control according to paired-samples $t$-test. 